\title{
Probabilistic seismic hazard assessment of Peshawar District, Pakistan
}

\author{
Ahmad Hammad Khaliq ${ }^{1}$, Muhammad Waseem $^{1}$, Sarfraz Khan ${ }^{1, *}{ }^{\infty}$, \\ Waqas Ahmed ${ }^{1}$ and Muhammad Asif Khan ${ }^{2}$ \\ ${ }^{1}$ National Centre of Excellence in Geology, University of Peshawar, Peshawar, KP 25130, Pakistan. \\ ${ }^{2}$ University of Peshawar, Peshawar, KP 25130, Pakistan. \\ ${ }^{*}$ Corresponding author.e-mail: sarfraz_qau@yahoo.com
}

MS received 16 August 2016; revised 12 April 2018; accepted 17 April 2018; published online 20 November 2018

The seismic provisions for the Building Code of Pakistan were revised after the 2005 Kashmir earthquake and these have resulted in the introduction of a macrozonation ground motion hazard map in the seismic provisions. The macrozonation map proposes a peak ground acceleration (PGA) for the return period of 475 yr for Pakistan for flat rock sites. After the macrozonation, the next step is to develop the surface ground motion assessment studies for the cities, districts and tehsils of Pakistan. In this study, the probabilistic seismic hazard analysis (PSHA) approach is used for the Peshawar District. The PSHA, consistent with the classical Cornell approach, is carried out to obtain the seismic hazard curves and uniform hazard spectra of PGA values for the return periods of 150, 475, 975 and $2475 \mathrm{yr}$ at a grid spacing of $0.1^{\circ} \times 0.1^{\circ}$. The PGA for Peshawar at $150,475,975$ and $2475 \mathrm{yr}$ return period is estimated as 0.23 , $0.34,0.39$ and $0.45 \mathrm{~g}$, respectively, for rock flat outcrop site conditions. The surface ground motion maps proposed in this study incorporate the local soil effects using amplification factors based on shear wave velocity obtained as a proxy to the topographic slope. The resultant ground surface hazard assessment proposes the PGA value of $0.63 \mathrm{~g}$ for the return period of $475 \mathrm{yr}$ and $0.89 \mathrm{~g}$ for the return period of 2475 yr. The maps developed in the current study are important inputs for the structural designing, risk assessment and land use planning of the Peshawar District.

Keywords. Probabilistic seismic hazard assessment; disaggregation; site classification; ground surface hazard assessment; Peshawar.

\section{Introduction}

Pakistan is among the most seismically active regions of the world as it lies at the collision boundaries of the Indian, Eurasian and Arabian plates. In the north, the plate boundary is of convergent nature due to the Indian plate subducting beneath the Eurasian plate, moving at the rate of $37-42 \mathrm{~mm} / \mathrm{yr}$ (Chen et al. 2000; Shen et al. 2000). In the west, the plate boundary is transform in nature marked by the Chamman fault. In the south, the Arabian plate is converging with the Eurasian plate at the rate of 28-33 $\mathrm{mm} / \mathrm{yr}$ (Apel et al. 2006) along the Makran subduction zone. Major earthquakes have occurred along these plate boundaries in the recent past, including 1905 Kangra $(\mathrm{M} \sim 8)$; 1935 Quetta (M 7.6); 1945 Makran (M 8.3); 1992 Chamman (M 6.2); 2005 Kashmir (M 7.6); and 2015 Hindukush (M 7.5) earthquakes. After the Kashmir 
Input

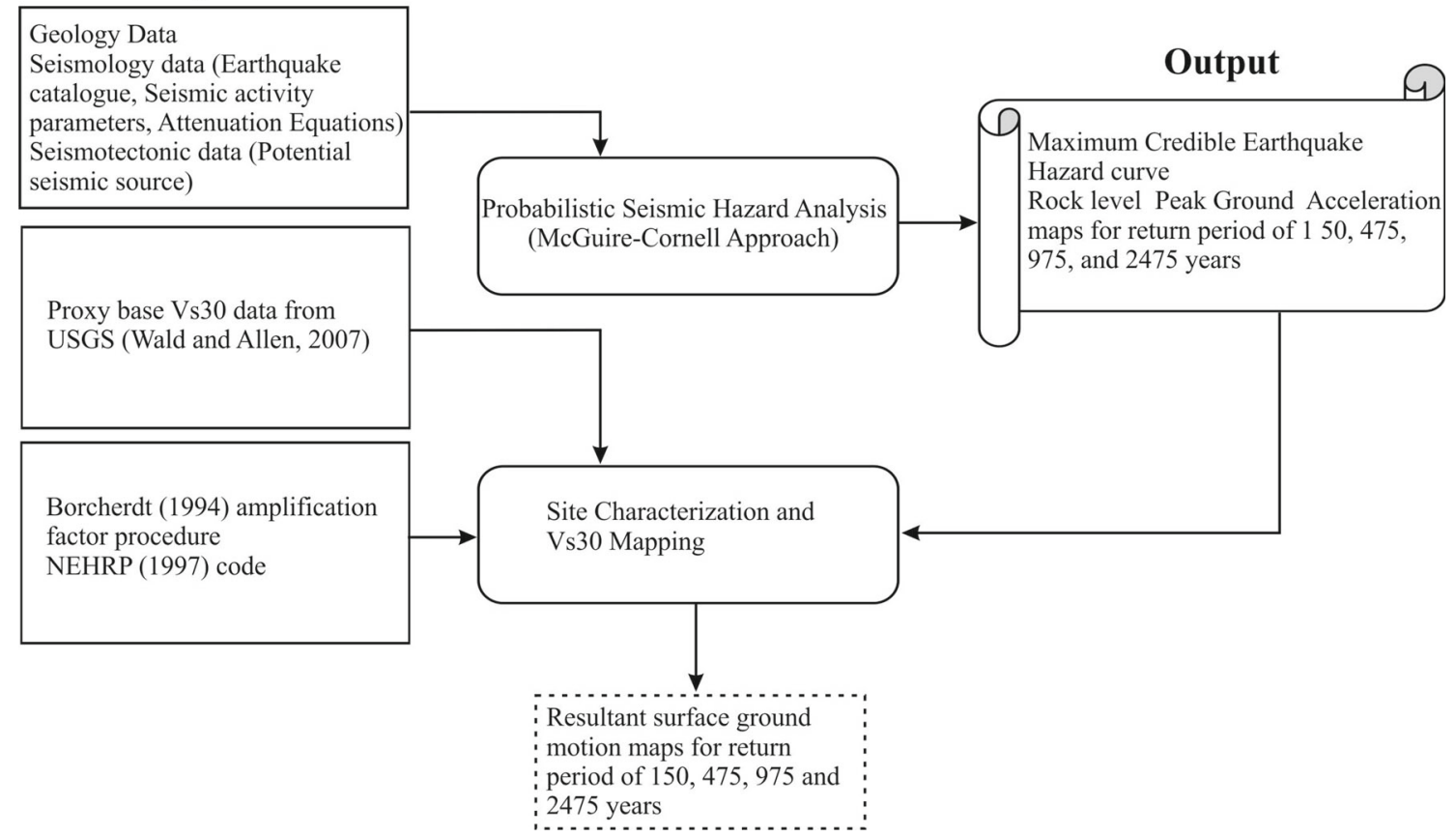

Figure 1. A detailed work flow chart of the method, inputs and output parameters that are used in the surface hazard assessment study.

earthquake, the Building Code of Pakistan (BCP) was revised, seismic provisions for buildings were introduced and macrozonation maps were developed assuming ground as a flat rock (e.g., PMD and NORSAR 2007; BCP 2007; MonaLisa et al. 2007). After the macrozonation map, the next logical step is to develop surface ground motion maps for different cities, districts and tehsils of the country. These maps will be used for designing structures, vulnerability-risk assessment, city planning and land use.

In the current study, surface ground motion maps are proposed for Peshawar District that includes major townships, i.e., Hayatabad, Ragi Lalma, Western Cantonment including the Bachcha Khan International Airport, University Town and University Campus, Ghariza and many small villages in the immediate vicinity. Peshawar District is selected as the study area based on its administrative, cultural and geographic importance as well as the rapid population and infrastructure growth.

Probabilistic seismic hazard analysis (PSHA) is carried out following the Cornell-McGuire (Cornell 1968; McGuire 1976) approach based on definitions of area seismic sources. The results of PSHA are expressed as peak ground acceleration (PGA) values for the return periods of $150,475,975$ and 2475 yr for flat rock ground condition (i.e., shear wave velocity $760 \mathrm{~m} / \mathrm{s}$ ). The local soil characterisation carried out for the study area is based on the topographic slope as proxy shear wave velocity (Wald and Allen 2007). Amplification factors are computed based on NEHRP (1997) recommendations and Borcherdt (1994) procedures which are integrated with PSHA ground acceleration to obtain the final maps. The methodology used in this study is explained in the flow chart as shown in figure 1.

The surface ground motion values for the return period of $475 \mathrm{yr}$ range from 0.54 to $0.63 \mathrm{~g}$ and for the return period of $2475 \mathrm{yr}$, the average ground surface acceleration is calculated as $0.79-0.89 g$.

By filling the gaps in the previous research studies which did not consider soil and subsoil conditions (PMD and NORSAR 2007; BCP 2007; MonaLisa et al. 2007), this study provides a realistic and practical approach for developing building codes, risk assessment and other engineering practices. The first attempt on the surface hazard assessment of the Peshawar District has been made in this study. The amplification of earthquake ground motions due to local soil effects are incorporated in this analysis. 
Table 1. Comparisons of peak ground acceleration value for return period of 475 years estimated in this study with previous seismic hazard studies.

\begin{tabular}{|c|c|c|c|}
\hline Sl. no. & Author & PGA $(g)$ & Zone assigned \\
\hline 1 & Zhang et al. (1999) & $0.16-0.24$ & Moderate hazard \\
\hline 2 & Bhatia et al. (1999) & $0.10-0.15$ & - \\
\hline 3 & Pakistan Meteorological Department Map of 1999 & $0.05-0.067$ & Zone IV \\
\hline 4 & Geological Survey of Pakistan Seismic Zoning Map of 2006 & $0.03-0.10$ & - \\
\hline 5 & MonaLisa et al. (2007) & 0.15 & - \\
\hline 6 & BCP (2007) & $0.16-0.24$ & $2 \mathrm{~B}$ \\
\hline 7 & Hashash et al. (2012) & $0.20-0.40$ & - \\
\hline 8 & Rafi et al. (2012) & 0.17 & - \\
\hline 9 & Saeed and Warnitchai (2012) & $0.33-0.40$ & - \\
\hline 10 & Current study & $0.32-0.34$ & - \\
\hline
\end{tabular}

\section{Current status of hazard assessment for the Peshawar District}

After the 2005 Kashmir earthquake, the Peshawar District was assigned different levels of seismic hazards in the regional framework of seismic hazard zonation maps of Pakistan. Previously, the seismic hazard zonation map of Pakistan of 1986 Pakistan Building Code classified the Peshawar District as zone 2 (moderate damage corresponds to intensity V-VI of Modified Mercalli Intensity scale of 1931) (Naseer et al. 2010; Khan et al. 2011). Other regional level seismic hazard assessments that partially address the Peshawar District include: Zhang et al. (1999) PGA 0.166-0.244g; Bhatia et al. (1999) PGA 0.10-0.15g and 1999 Pakistan Meteorological Department Map PGA 0.05-0.067g.

In comparison to these regional-level hazard assessments, recently some studies have been conducted for the Peshawar District (e.g., Geological Survey of Pakistan (2006) Seismic Zoning Map of 2006, PGA 0.03-0.10g; BCP (2007) PGA 0.160.24g; MonaLisa et al. 2007 PGA 0.150g; Hashash et al. (2012) PGA 0.20-0.40g; Rafi et al. (2012) PGA 0.175g; Saeed and Warnitchai (2012) PGA 0.33-0.40g; and Waseem et al. (2018) PGA 0.376g (for the $475 \mathrm{yr}$ return period) (table 1).

\section{Geology and tectonic settings of northwest Pakistan}

The tectonics of Pakistan is mainly controlled by the three major terrains which include from north to south Eurasian plate, Kohistan-Ladakh terrene and Indian plate. This Kohistan-Ladakh terrene is an intra-oceanic island arc formed in response to subduction within the Tethys Ocean (Tahirkheli and Jan 1979; Burg 2011). The terrane collided first with the Eurasian plate forming a northern suture termed Shyoke suture and later collided with the Indian plate along a southern suture called Indus suture (Searle et al. 1999; Shaltegger et al. 2002). The latter collision events resulted in the obduction of island arc sequence on to the Indian plate rocks (Tahirkheli and Jan 1979). The collision of these tectonic units resulted in the formation of the active Himalayan orogenic system, which is further classified into Tethyan Himalayas, Higher Himalayas, Sub-Himalayas and Lesser Himalayas (Gansser 1964). These divisions are based on major boundary faults which separated these tectonic blocks from each other. These boundary faults include from south to north Main Frontal Thrust or Salt Range Thrust, Main Boundary Thrust (MBT), Main Central Thrust, Main Mantle Thrust, Main Karakoram Thrust and Tibetan Detachment System.

The Peshawar basin covers over a large area of approximately $5500 \mathrm{~km}^{2}$ in the southwestern part of the Himalayas. The basin is bounded by Khairabad Fault, an equivalent of the Panjal Thrust in the Kashmir Himalayas to the south and the Indus Suture Zone to the north. This part of the Himalayas is variably interpreted to be as the Lesser Himalayas (Tahirkheli 1982) and Tethyan Himalayas (DiPietro and Pogue 2004).

Internally, the Peshawar basin (figure 2) comprises of Quaternary sediments that include fluvial gravel sands and lacustrine deposits. However, the outer fringes of the basin are predominantly fanglomerate derived from adjacent encircling mountains such as Malakand-Lower Swat Ranges in the north, Attock-Cherat-Dara 


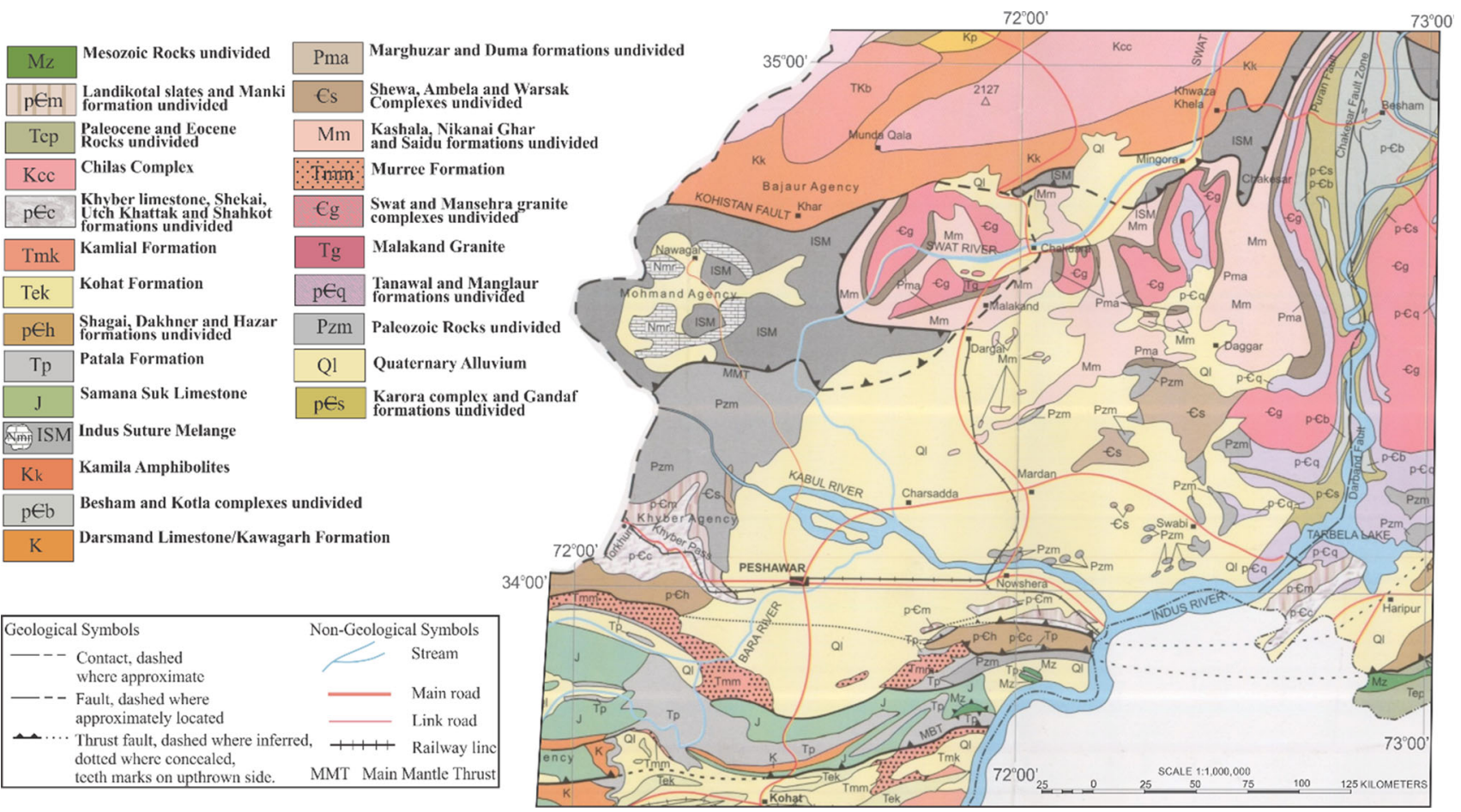

Figure 2. Detailed geological map of the Peshawar District and its surrounding areas (modified after Khan et al. 2006).

Adamkhel Ranges in the south and the Khyber Ranges to the west (Burbank and Tahirkhali 1985; Kazmi and Jan 1997). Sediments of the Peshawar basin have been impounded by the uplifting of the Attock-Cherat Range and movement on MBT located at its southern fringes (Burbank and Raynolds 1988).

\section{Seismic hazard assessment and surface ground motion study}

\subsection{Earthquake catalogue compilation and processing}

Seismic hazard assessment using PSHA requires a complete data of earthquake history of the region of interest and it is the first step towards performing the seismic hazard study. Earthquake catalogue helps in identifying the sources and in the establishment of the recurrence law for seismic sources.

The earthquake catalogue compiled in this study contains both instrumental and historical seismicity records. For instrumental records, both National and International dataset networks such as National Earthquake Information Centre (NEIC), British Association for the Advancement of Science (BAAS), International Seismological
Summary (ISS), International Seismological Centre (ISC) were considered for developing the seismicity catalogue for northern Pakistan. For historical earthquakes, we used several compilations from published literature (e.g., Oldham 1883; Quittmeyer et al. 1979; Bilham 1998; Ambraseys and Bilham 2003; Bilham et al. 2007; Heidarzadeh et al. 2008; Ambraseys and Bilham 2009; Bilham and Lodhi 2010; Martin and Szeliga 2010). These studies have listed important earthquakes that occurred in Pakistan and surrounding region and furnish important information sources for historical earthquakes. Earthquake catalogue compiled in this study also contains the information about the significant earthquakes after the 1900 yr. The compiled catalogue for this study covers latitude of $31.26-36.71^{\circ}$ and longitude of $68.64-75.28^{\circ}$ (figure 3 ). The minimum threshold of 4.0 $\mathrm{M}$ is set for this catalogue in order to be consistent with the similar regional studies.

After the compilation of the earthquake catalogue, the following process was carried out. Firstly, duplicate earthquake events are removed based on the time of occurrence and location. The catalogue was further processed to obtain a homogenised magnitude scale $\left(M_{w}\right)$ for all the events. The catalogue has been compiled from different sources (local and international) and it 

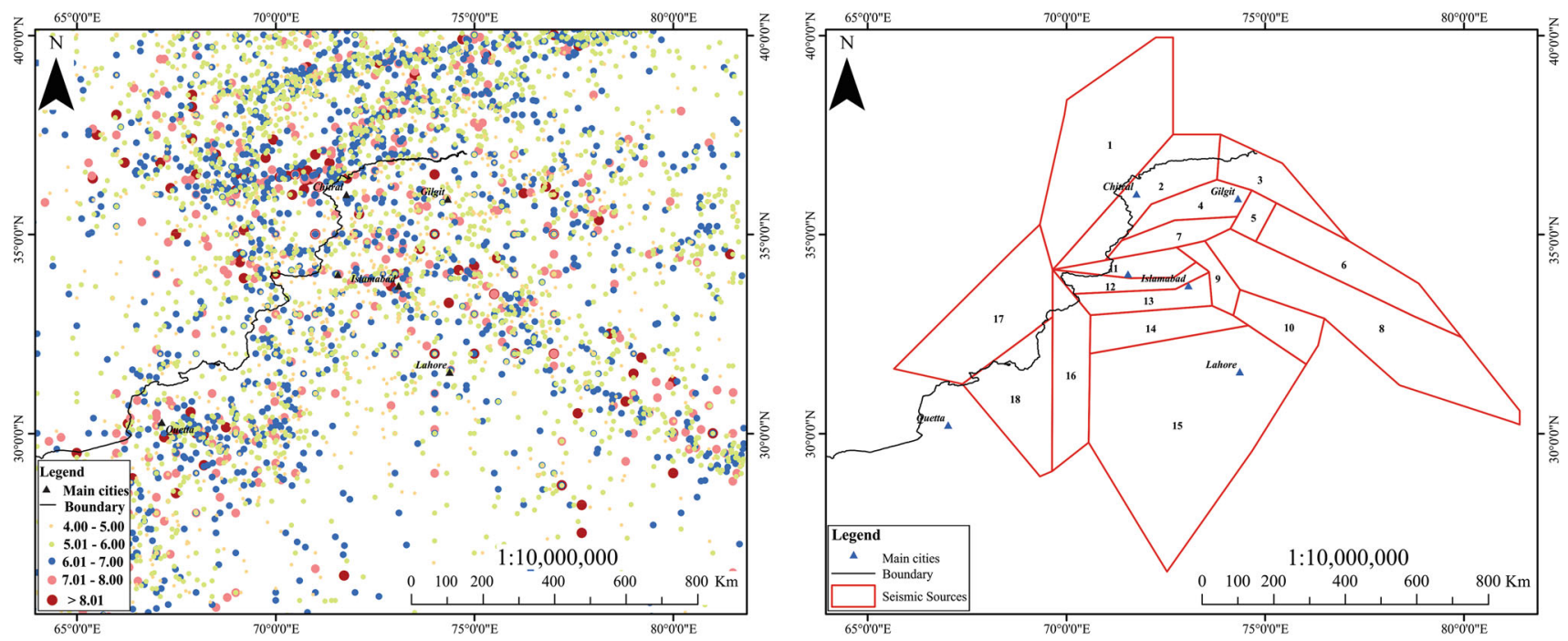

Figure 3. Seismic area sources with processed earthquake catalogue of NW Pakistan. The declustered earthquake catalogue shows the distribution of seismicity (left figure) with different magnitude intervals in the selected area seismic sources in this study.

contains events reported in local $\left(M_{\mathrm{L}}\right)$, body wave $\left(m_{b}\right)$ and surface wave $\left(M_{\mathrm{S}}\right)$ magnitude scales. These magnitudes were converted to the moment magnitude $\left(M_{w}\right)$ by using an empirical relation presented by Ambraseys and Bommer (1990) and Scordilis (2006).

The preliminary requisite for PSHA is to remove accessory events (dependents events) and assessment of the completeness of earthquake data in the catalogue. Therefore, two types of processing checks are performed on the catalogue: (i) removal of dependent events and (ii) completeness period of earthquakes. Earthquake-dependent events are removed using the declustering process through time and distance windows criteria of Gardner and Knopoff (1974). This processing led to a total of 1749 out of 6318 . As the shallow earthquakes are critical for seismic hazards, records over 70 $\mathrm{km}$ depth were removed. Earthquake catalogue is usually complete for large events and for small events it may not be complete. After removing the dependent events, completeness analysis of the declustered catalogue has been performed using the visual cumulative method (VCM) proposed by Tinti and Mulargia (1985) to identify the completion periods by defining magnitude classes of $4.0-4.5 ; 4.5-5.0 ; 5.0-5.5 ; 5.5-6.0 ; 6.0-6.5 ; 6.5-7.0$; and $\geq 7.0$. Minimum threshold magnitude (4.0) was considered because small events $(M<4.0)$ are usually incomplete in earthquake catalogues.

The VCM involves developing plots of the cumulative number of earthquake events and time from the beginning of the catalogue for different earthquake magnitude classes. The period of completeness for a given class is considered to begin from the earliest time when the slope of the fitting curve can be approximated by a straight line. The VCM for the complete catalogue is shown in figure 4 and the year of the magnitude of completeness is given in table 2 .

\subsection{Seismic sources}

Definition of the seismic sources is an important step for the hazard assessment framework following the Cornell-McGuire approach (Cornell 1968; McGuire 1976). Area polygons are used as seismic sources in this study because it was difficult to associate earthquakes with faults.

In the context of Pakistan, negligible work has been carried out before for the identification and delineation of the seismic sources in Pakistan. Commonly, seismicity is the basis for defining the seismic sources in Pakistan. In this approach, regions with uniform seismicity are chalked out as polygons defining seismic source zones (e.g., NORSAR and PMD 2006). Earthquake data in Pakistan, especially earlier than mid-1970s, are of poor quality and incomplete and therefore, the seismic sources based on seismicity data alone are often misleading. This can be judged from the fact that seismic source zones do not coincide with the tectonic trend of the fault zones and often straddle regions of diverse tectonic settings, which is contrary to the basic objective of seismic source zone delineation. Some of the recent studies in 

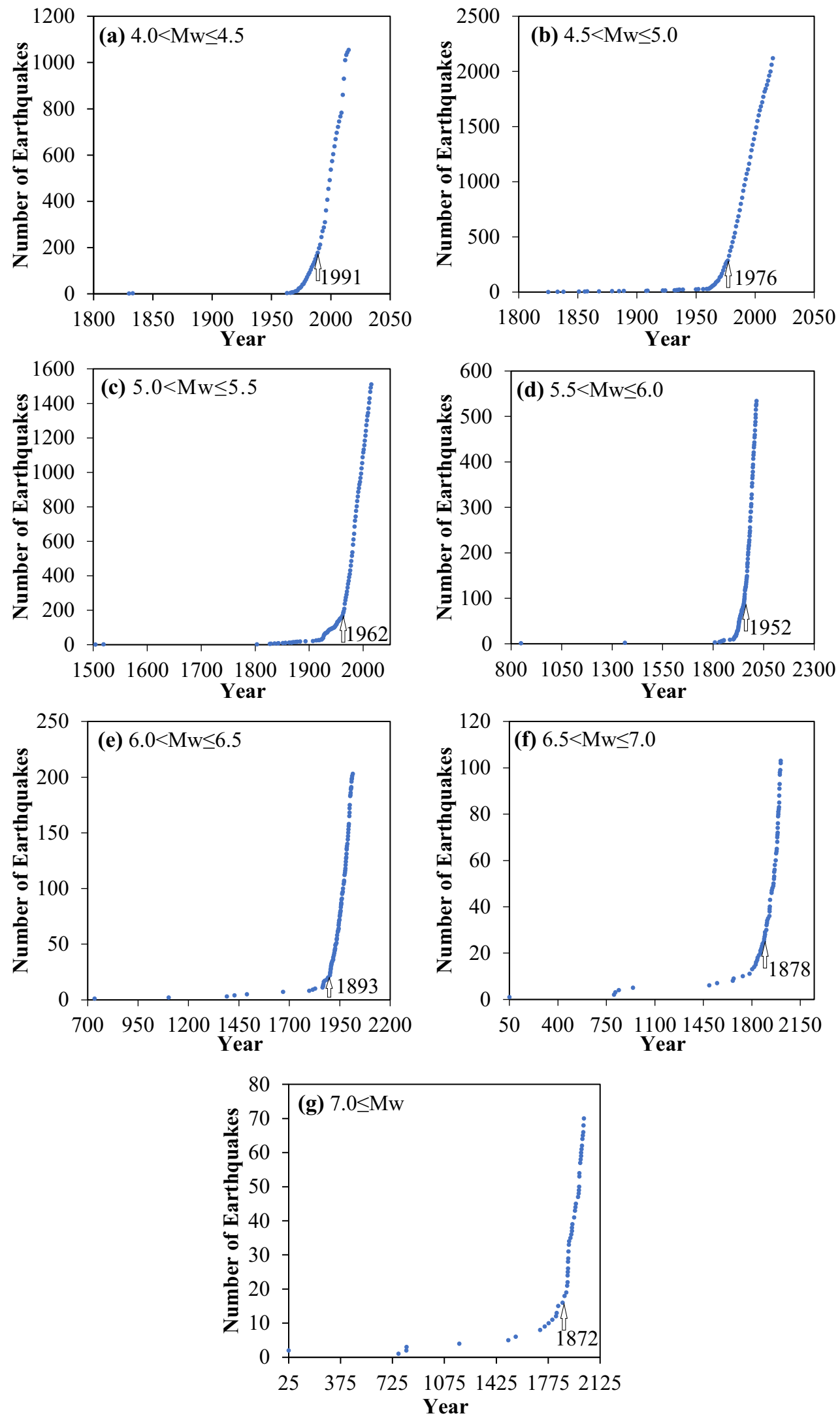

Figure 4. Completeness analyses of the earthquake catalogue using VCM. 
Table 2. Completeness analysis of the seismicity catalogue for different magnitude ranges.

\begin{tabular}{llc}
\hline $\begin{array}{c}\text { Sl. } \\
\text { no. }\end{array}$ & $\begin{array}{c}\text { Earthquake } \\
\text { magnitude range }\end{array}$ & $\begin{array}{c}\text { Completeness } \\
\text { year }\end{array}$ \\
\hline 1 & $4.0<M_{w} \leq 4.5$ & 1991 \\
2 & $4.5 \leq M_{w}<5.0$ & 1976 \\
3 & $5.0<M_{w} \leq 5.5$ & 1962 \\
4 & $5.5<M_{w} \leq 6.0$ & 1952 \\
5 & $6.0<M_{w} \leq 6.5$ & 1893 \\
6 & $6.5<M_{r m w} \leq 7.0$ & 1878 \\
7 & $7.0 \leq M_{w}$ & 1872 \\
\hline
\end{tabular}

Pakistan have therefore taken into account not only the seismicity but also the active faults (BCP 2007; MonaLisa et al. 2007; Hashash et al. 2012). However, the quality of the fault map used in these studies is of poor quality which has introduced limitations to the accurate seismic source zone delineation.

Seismicity combined with tectonic zones of uniform geology, tectonic settings and the combination of faults characteristic of that specific tectonic zone was used in seismic source zoning. This approach in Pakistan was first adopted for the 2007 BCP study, and then refined by Khan et al. (2011) in Earthquake Model of Middle East (EMME) international project.

In order to determine the seismic hazard of the Peshawar District, area seismic sources were considered in a radius of $\sim 200 \mathrm{~km}$ around the study area on the basis of seismicity of the region and its tectonic structure. Earthquakes and source zones away from this buffer are not considered because it is believed that distant earthquakes do not directly affect the site. In this study, 18 seismic sources (table 3 and figure 2) are considered for PSHA.

\subsection{Earthquake recurrence model}

Gutenberg-Richter (G-R) Law (Gutenberg and Richter 1944) is used to estimate the mean annual exceedance rate $\left(\lambda_{m}\right)$ of different magnitude $\left(M_{o}\right)$ in a specific period of time (period in which the catalogue is considered to be complete). This law predicts higher rates for the smaller earthquake and lower rates for larger magnitude earthquake that is consistent with observations.

Mean annual rate of exceedance $\left(\lambda_{m}\right)$ is the number of earthquake events per year of magnitude equal to or greater than ' $M$ '. The empirical relation of frequency magnitude relation is expressed as:

$$
\log \lambda_{m}=a-b * M_{o}
$$

where ' $\lambda_{m}$ ' is the annual rate of exceedance of magnitude ' $M_{o}$ '; ' $a$ ' is a hypothetical number of earthquakes per year above the zero magnitude and ' $b$ ' gives the relation between the number of smaller and larger earthquakes. Standard $\mathrm{G}-\mathrm{R}$ recurrence of equation (1) is exponentially expressed as

$$
\lambda_{m}=10^{a-b M_{\mathrm{o}}}=\exp \left(\alpha-\beta M_{o}\right),
$$

where $\alpha=a \ln (10)$ and $\beta=b \ln (10)$ in equation (2) shows that the earthquake distributed exponentially and it covers the range of magnitude from $-\infty$ to $+\infty$ (Kramer 1996).

The standard G-R relationship covers an infinite range of magnitudes. The effect of small magnitude is not of interest for the engineering purposes (Waseem et al. 2018). Moreover, the standard $\mathrm{G}-\mathrm{R}$ relationship predicts the non-zero rate of exceedance for very large events. Therefore, the bounded G-R equation (3) proposed by Cornell and Vanmarcke (1969) has been used:

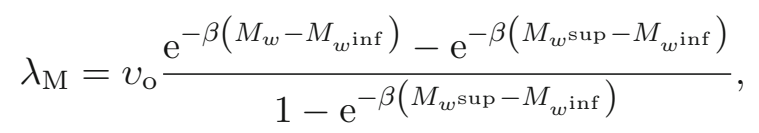

where $v_{\mathrm{o}}=\exp \left(\alpha-\beta M_{w_{\text {inf }}}\right)$; and $M_{w^{\text {inf }}}$ and $M_{w^{\text {sup }}}$ are the lower and upper bounds of moment magnitude $\left(M_{w}\right)$, respectively.

If the value of ' $b$ ' decreases, the likelihood of the large earthquake will be increased for the same ' $a$ ' value. The maximum likelihood method proposed by Weichert (1980) is used for the determination of $\mathrm{G}-\mathrm{R}$ relationships (' $a$ ' and ' $b$ ' values) for seismic source zones defined in northern Pakistan. All the computed seismicity parameters are given in table 3 .

\subsection{Ground motion prediction equations (GMPEs)}

A GMPE is a statistical model to predict the level of ground shaking and associated uncertainties at the site of interest. It takes into account earthquake magnitude, fault mechanism, source-to-site distance, local site conditions, etc. as predictive variables, and is used to estimate the ground motion parameters such as PGA, peak ground velocity $(\mathrm{PGV})$ and spectral acceleration at different vibration periods. 
Table 3. Earthquake sources zone parameters used for the computations of hazard for the study area where, $N$ is the number of earthquake events; $M_{w}$ the threshold magnitude; $\lambda_{m}$ the exceedance rate with threshold magnitude 4.0.

\begin{tabular}{llrrrrr}
\hline Sl. no. & \multicolumn{1}{c}{ Seismic sources } & $N$ & $M_{w}$ & Max. $M_{w}$ & $a$ value & $b$ value \\
\hline 1 & Hindukush Seismic Zone & 281 & 4.0 & 7.3 & 3.373 & 0.601 \\
2 & Chitral Seismic Zone & 96 & 4.0 & 7.4 & 2.737 & 0.563 \\
3 & Karakoram Seismic Zone & 48 & 4.0 & 6.4 & 2.906 & 0.668 \\
4 & Northern Kohistan Seismic Zone & 50 & 4.0 & 7.4 & 2.393 & 0.550 \\
5 & Nanga Parbat Seismic Zone & 19 & 4.0 & 6.1 & 3.037 & 0.789 \\
6 & Deosi Ladakh Seismic Zone & 58 & 4.0 & 6.7 & 2.609 & 0.583 \\
7 & Southern Kohistan Seismic Zone & 51 & 4.0 & 6.9 & 2.828 & 0.645 \\
8 & Kashmir Kaghan Zone & 223 & 4.0 & 7.6 & 3.283 & 0.603 \\
9 & Kashmir Syntaxes Zone & 31 & 4.0 & 7.6 & 2.929 & 0.716 \\
10 & Eastern Kashmir Himalaya Zone & 59 & 4.0 & 7.8 & 2.390 & 0.533 \\
11 & Hazara Peshawar Seismic Zone & 55 & 4.0 & 6.5 & 3.007 & 0.678 \\
12 & Punjal MBT Seismic Zone & 92 & 4.0 & 7.4 & 2.474 & 0.584 \\
13 & Northern Potwar Zone & 59 & 4.0 & 6.4 & 3.274 & 0.731 \\
14 & Potwar Salt Range Zone & 81 & 4.0 & 6.6 & 3.436 & 0.736 \\
15 & Punjab Plains & 186 & 4.0 & 7.0 & 3.921 & 0.765 \\
16 & Kurram Waziristan Seismic Zone & 134 & 4.0 & 6.7 & 3.312 & 0.659 \\
17 & Chamman Zone & 118 & 4.0 & 7.6 & 2.921 & 0.584 \\
18 & Inner Suleiman Seismic Zone & 108 & 4.0 & 6.9 & 3.272 & 0.671 \\
\hline
\end{tabular}

Strong-motion records are either absent or available in small numbers in Pakistan. This hinders formulations of GMPEs specific to tectonic conditions in Pakistan. In the absence of locally derived GMPEs, the only alternative is to adopt the attenuation equation derived in other regions that are tectonically and geologically similar to Pakistan. In the current study, Boore and Atkinson (2008) next generation attenuation (NGA) and Akkar and Bommer (2010) attenuation relationships are considered to be equivalent to northern Pakistan.

The NGA program sponsored by Pacific Earthquake Engineering Research (PEER) developed GMPEs for active shallow crustal tectonic regions of the world. In addition to Boore and Atkinson (2008) NGA, four other equations are proposed in the NGA program (i.e., Abrahamson and Silva 2008; Campbell and Bozorgnia 2008; Chiou and Youngs 2008; Idriss 2008).

Ground motion values predicted by these two GMPEs are truncated at sigma +3 values. The selection of these GMPEs is based on a low variability and limited input parameters as compared to others. Additionally, these GMPEs are developed from strong motion data collected in shallow crustal tectonic settings, which is similar to the tectonic setting in northern Pakistan.

\subsubsection{Boore and Atkinson 2008 NGA relationship}

Boore and Atkinson (2008) attenuation relationship for mean horizontal component comprises PGA, PGV and 5\% damped spectral periods between 0.01 and $10.0 \mathrm{~s}$. The PEER NGA derived the empirical equation for the shallow crustal earthquake in the active tectonic regime of the world. This equation shows the significant modification of GMPEs that was published by Boore et al. (1997). The general form of equation (4) is given below:

$$
\begin{aligned}
\ln Y= & M * F_{\mathrm{M}}+F_{\mathrm{D}}\left(R_{\mathrm{JB}}, M\right) \\
& +F_{\mathrm{S}}\left(V_{\mathrm{s} 30}, R_{\mathrm{JB}}, M\right)+\epsilon \sigma_{T},
\end{aligned}
$$

where $Y$ is the earthquake intensity; $F_{\mathrm{M}}$ the magnitude scaling factor; $F_{\mathrm{D}}$ the distance function; $F_{\mathrm{S}}$ the site amplification; $M$ the moment magnitude; $R_{\mathrm{JB}}$ the Joyner-Boore distance; $V_{\mathrm{s} 30}$ the average shear-wave velocity (top $30 \mathrm{~m}$ depth); $\epsilon$ the fractional number of standard deviations for predicted values of higher and lower $\ln Y$ from the mean value and coefficient $\sigma_{T}$ is period dependent is computed as $\sigma_{T}=\sqrt{\left(\sigma^{2}+\tau^{2}\right)}$, where $\sigma$ is the intra-event aleatory uncertainty and $\tau$ is the inter-event aleatory uncertainty. 


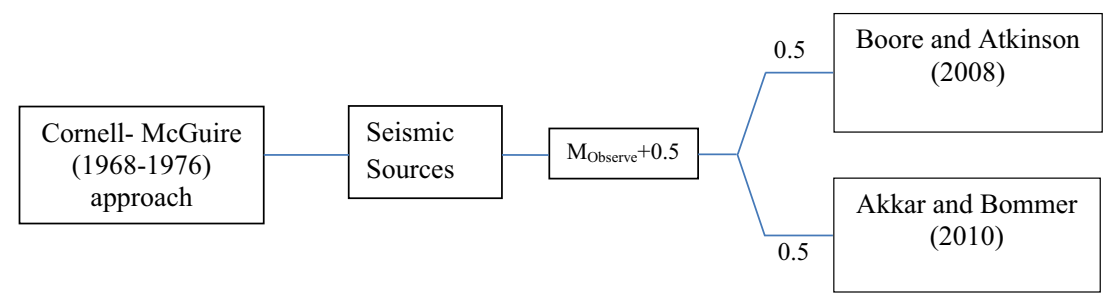

Figure 5. The logic tree used in PSHA.

\subsubsection{Akkar and Bommer (2010) GMPE}

The recently published Akkar and Bommer (2010) GMPE is the updated version of Akkar and Bommer (2007) used for predicting the PGV, PGA and response spectral ordinates in Europe, the Middle East and the Mediterranean (Akkar and Bommer 2007). This empirical GMPE is derived from the large dataset from several countries (Europe, Africa and the Middle East) which have moderateto-high seismicity.

The selected attenuation relationship of Akkar and Bommer (2010) GMPE is the same dataset used by Akkar and Bommer (2007) for the prediction of pseudo-spectral acceleration 5\% damped spectral periods between 0.0 and $3.0 \mathrm{~s}$. The empirical form of the equation is as given below:

$$
\begin{aligned}
\log (\mathrm{PSA})= & b_{1}+b_{2} M+b_{3} M^{2} \\
& +\left(b_{4}+b_{2} M\right) \log \sqrt{R_{\mathrm{JB}}^{2}+b_{6}^{2}} \\
& +b_{7} S_{\mathrm{S}}+b_{8} S_{\mathrm{A}}+b_{9} F_{\mathrm{N}}+b_{10} F_{\mathrm{R}}+\delta,
\end{aligned}
$$

where $S_{\mathrm{S}}$ and $S_{\mathrm{A}}$ are used to define the site based on $V_{\mathrm{s} 30}$ value (soft, stiff or rock). Similarly, $F_{\mathrm{N}}$ and $F_{\mathrm{R}}$ are the normal and reverse faulting earthquakes, respectively. The maximum likelihood method of Joyner and Boore (1993) is applied for deriving the coefficients. $\sigma$ is the total standard deviation given by square root of the sum of the variability of an inter-event $\left(\sigma_{2}\right)$ and an intra-event $\left(\sigma_{1}\right)$ components.

\subsection{Hazard analyses}

The ground motion estimation is carried out using PSHA based on the Cornell-McGuire (Cornell 1968; McGuire 1976) approach at a grid size of $0.1^{\circ} \times 0.1^{\circ}$. The Crisis 2015 Ver. 3.2 (Ordaz et al . 2015) numerical code has been used for estimation of ground motions for rock site conditions. The maximum magnitude assigned to sources is determined by the maximum observed magnitude in the seismic source plus 0.5 units.
The epistemic uncertainty is considered only for the GMPEs using the logic tree in PSHA. The logic tree is shown in figure 5 . The logic tree has two branches for the GMPEs. Each GMPE has been assigned to each source having equal weights in the logic tree.

Results of PSHA are obtained in terms of PGA contour maps; hazard curve and uniform hazard spectra (UHS) (figures 6 and 7) (latitude: 71.54; longitude: 34.01). The measured hazard contour maps of the Peshawar District in terms of the rock PGA values at $150,475,975$ and 2475 yr are given in figure 8 and tabulated in table 4 . PGA ranges from 0.32 to $0.35 g$ in the Peshawar District for the return period of $475 \mathrm{yr}$ and from 0.44 to $0.48 \mathrm{~g}$ for the return period of $2475 \mathrm{yr}$.

\subsection{Disaggregation}

The disaggregation is a way to identify earthquake events contributing to a selected seismic-hazard level. To understand which size and distance range contribute most to PSHA, disaggregation is the most vital step in PSHA. It is an essential step to have a particular earthquake compatible to PSHA results for taking significant engineering decisions (Trifunac 1989). Disaggregation provides data on the magnitude and distance of the seismic sources to be used for generating scenario earthquakes and to select related seismic design time histories. It does not consider the single earthquake, instead it considers all the likely earthquakes that can occur and calculate the rate of expected ground motion parameters at the site. Disaggregation deconvolves the total hazard of a site to generate various single scenarios. Disaggregation shows the distinctive magnitude and distance of earthquake events contributing the most to the seismic hazard for the $10 \%$ probability of exceedance in $50 \mathrm{yr}$ (return period $475 \mathrm{yr}$ ) at the selected sites. Figure 9 shows the disaggregation for the PGA at return periods of $150,475,975$ and $2475 \mathrm{yr}$ at the Peshawar District. Disaggregation result for the 


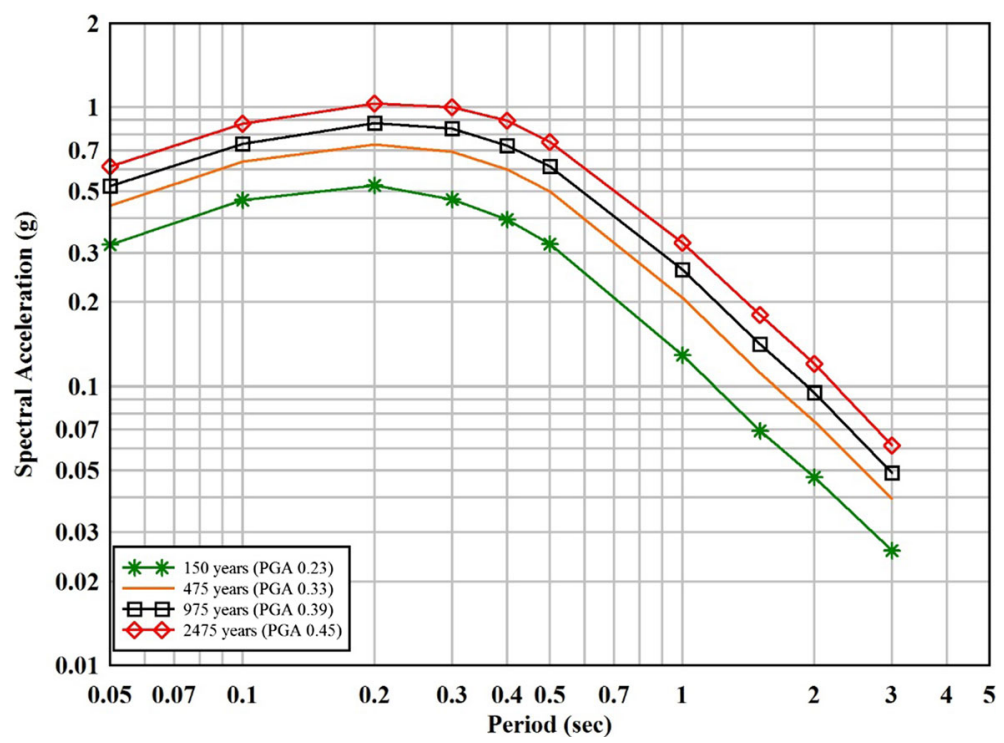

Figure 6. UHS for Peshawar District for the return periods of 150, 475, 975 and 2475 yr using the median value of Boore and Atkinson (2008) and Akkar and Bommer (2010) GMPEs.

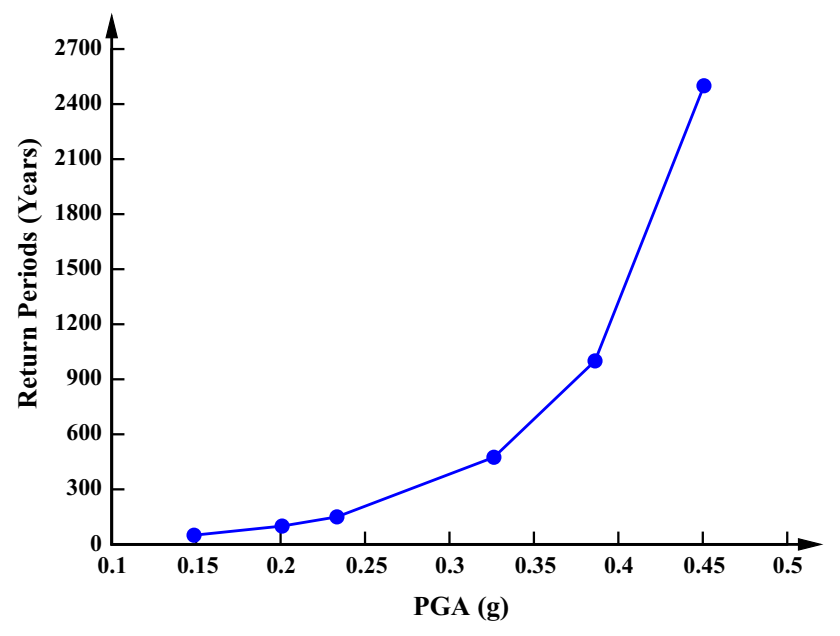

Figure 7. PGA vs. return period curve for the Peshawar District.

return period of $475 \mathrm{yr}$, suggests that most of the contribution to hazard belongs to $M w 5-6$ occurring at a distance of $0-10 \mathrm{~km}$ range. Earthquake of magnitude 6.0 occurring at a distance of $5 \mathrm{~km}$ can be assumed as the controlling earthquake for the site (based on results for the return period of $475 \mathrm{yr})$.

\subsection{Hazard assessment at surface}

Risk of damage to structures at surfaces is of large extent, which is determined by degree and nature of surface ground movements and physical properties of structures themselves. A more direct approach to compute hazard at ground surface for seismic risk at the site would be to characterise the response of ground motion to seismic energy by direct measurement and compare that response with shaking resonance of structures built on that site (Turnbull 2000). Mainly the hazard assessment at the surface is conducted using $\mathrm{H} / \mathrm{V}$ microtremor study, Nakamura method (ratio of horizontal to vertical amplification of weak motion data), response spectrum method and frequency domain amplification method (Green's function method) (Turnbull 2000).

Estimating site effects is of key importance to develop seismic site characterisation maps which are normally used for earthquake mitigation, awareness, response and retrieval. Seismic site characterisation maps for seismic site conditions are normally based on the averaged shear-wave velocity of the top $30 \mathrm{~m}$ earth surface $\left(V_{\mathrm{s} 30}\right)$ (Borcherdt 1994; Hartzell et al. 2001; Wills and Clahan 2006; Wald and Allen 2007; Yong et al. 2008; Castellaro and Mulargia 2009).

Wills and Silva (1998) have suggested the use of shear wave velocity for seismic site characterisation (Anbazhagan 2013). The $V_{\mathrm{s} 30}$ based seismic site characterisation maps have been effectively used by the United States of Geological Survey (USGS) in developing ground shaking maps, estimating seismic loss in near real time (Earle et al. 2008) and defining generalised seismic site categories by the National Earthquake Hazard Reduction Program (NEHRP) (table 5) (Wills et al. 2000). 

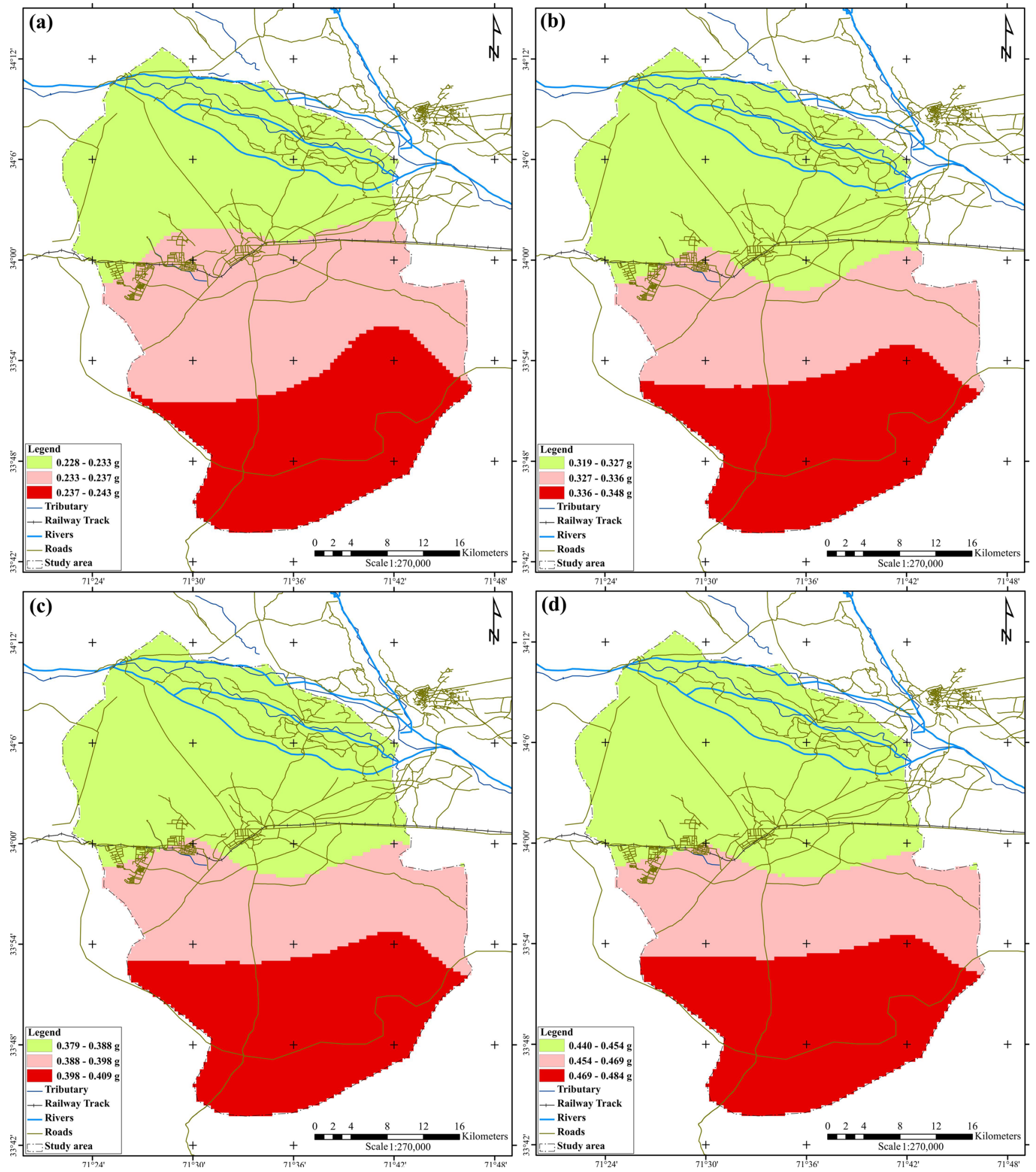

Figure 8. PGA contour map of the Peshawar District with return periods (Tr $T_{\mathrm{r}}$ of (a) $150 \mathrm{yr}$, (b) $475 \mathrm{yr}$, (c) $975 \mathrm{yr}$ and (d) $2475 \mathrm{yr}$.

In this study, soil characterisation is accomplished using the online USGS seismic site characterisation web database for active tectonic categories. NEHRP (1997) recommendations are used to classify the soils into soil sites ' $C$ ' and ' $D$ '. Table 6 summarises the soil site classifications of the study area based on the NEHRP code. These $V_{\mathrm{s} 30}$ values are used to develop the shear velocity 
Table 4. PGA (g) values for the return periods $\left(T_{r}\right)$ of $150,475,975$ and 2475 yr at bedrock level.

\begin{tabular}{|c|c|c|c|c|c|c|}
\hline \multirow[b]{2}{*}{ Name } & \multirow[b]{2}{*}{ Long. } & \multirow[b]{2}{*}{ Lat. } & \multicolumn{4}{|c|}{ PGA $(g)$ at return period $\left(T_{\mathrm{r}}\right)$} \\
\hline & & & $150 \mathrm{yr}$ & $475 \mathrm{yr}$ & $975 \mathrm{yr}$ & $2475 \mathrm{yr}$ \\
\hline Gul Bela & 71.64 & 34.12 & 0.230 & 0.321 & 0.382 & 0.445 \\
\hline Achini Bala & 71.46 & 33.90 & 0.235 & 0.335 & 0.396 & 0.467 \\
\hline Adezai & 71.56 & 33.77 & 0.241 & 0.345 & 0.407 & 0.482 \\
\hline Aza Khel & 71.65 & 33.80 & 0.239 & 0.343 & 0.405 & 0.480 \\
\hline Bada Ber Huri Zai & 71.58 & 33.87 & 0.237 & 0.337 & 0.399 & 0.471 \\
\hline Bada Ber Maryam Zai & 71.60 & 33.88 & 0.236 & 0.337 & 0.399 & 0.470 \\
\hline Bazid Khel & 71.56 & 33.93 & 0.234 & 0.332 & 0.393 & 0.462 \\
\hline Budhni & 71.66 & 34.04 & 0.232 & 0.324 & 0.384 & 0.447 \\
\hline Chaghar Matti & 71.49 & 34.11 & 0.229 & 0.320 & 0.381 & 0.444 \\
\hline Cham Kani & 71.64 & 33.97 & 0.234 & 0.329 & 0.389 & 0.454 \\
\hline Dag & 71.51 & 34.04 & 0.232 & 0.325 & 0.385 & 0.449 \\
\hline Garhi Sher Dad & 71.45 & 34.11 & 0.230 & 0.322 & 0.382 & 0.445 \\
\hline Haryana Payan & 71.56 & 34.05 & 0.232 & 0.323 & 0.384 & 0.447 \\
\hline Jogani & 71.47 & 34.16 & 0.230 & 0.322 & 0.382 & 0.445 \\
\hline Kafoor Dheri & 71.40 & 34.06 & 0.231 & 0.323 & 0.383 & 0.446 \\
\hline Kaniza & 71.52 & 34.07 & 0.230 & 0.322 & 0.383 & 0.446 \\
\hline Kankola & 71.63 & 34.05 & 0.232 & 0.323 & 0.383 & 0.447 \\
\hline Khatki & 71.56 & 34.15 & 0.229 & 0.320 & 0.381 & 0.444 \\
\hline Khazana & 71.60 & 34.05 & 0.232 & 0.324 & 0.384 & 0.447 \\
\hline Lala & 71.70 & 33.99 & 0.235 & 0.329 & 0.389 & 0.454 \\
\hline Laram & 71.57 & 34.01 & 0.233 & 0.325 & 0.385 & 0.449 \\
\hline Maryam Zai & 71.59 & 33.80 & 0.240 & 0.343 & 0.405 & 0.479 \\
\hline Mashu Gaggar & 71.54 & 33.85 & 0.238 & 0.340 & 0.402 & 0.475 \\
\hline Mathra & 71.47 & 34.06 & 0.231 & 0.323 & 0.383 & 0.447 \\
\hline Mira Kachori & 71.68 & 33.95 & 0.236 & 0.333 & 0.394 & 0.461 \\
\hline Mosa Zai & 71.61 & 33.95 & 0.235 & 0.331 & 0.391 & 0.458 \\
\hline Nahaqi & 71.65 & 34.08 & 0.231 & 0.322 & 0.382 & 0.445 \\
\hline Pajjagi & 71.55 & 34.04 & 0.232 & 0.324 & 0.384 & 0.448 \\
\hline Pakha Ghulam & 71.60 & 34.01 & 0.233 & 0.324 & 0.383 & 0.447 \\
\hline Palosi & 71.48 & 33.98 & 0.234 & 0.329 & 0.389 & 0.456 \\
\hline Panam Dheri & 71.41 & 34.10 & 0.231 & 0.323 & 0.383 & 0.445 \\
\hline Pashta Khara Payan & 71.52 & 33.93 & 0.234 & 0.332 & 0.393 & 0.462 \\
\hline Peshawar & 71.57 & 33.97 & 0.234 & 0.327 & 0.388 & 0.453 \\
\hline Regi & 71.44 & 33.99 & 0.232 & 0.327 & 0.387 & 0.453 \\
\hline Sarband & 71.50 & 33.92 & 0.233 & 0.332 & 0.394 & 0.464 \\
\hline Shahi Bala & 71.43 & 34.05 & 0.231 & 0.324 & 0.384 & 0.447 \\
\hline Sheikh Muhammad & 71.54 & 33.91 & 0.234 & 0.333 & 0.395 & 0.465 \\
\hline SheiKhan & 71.48 & 33.86 & 0.236 & 0.338 & 0.400 & 0.473 \\
\hline Sher Kera & 71.60 & 33.75 & 0.243 & 0.347 & 0.408 & 0.483 \\
\hline Soro Zai Bala & 71.64 & 33.86 & 0.238 & 0.339 & 0.401 & 0.473 \\
\hline Soro Zai Payan & 71.65 & 33.90 & 0.237 & 0.337 & 0.398 & 0.469 \\
\hline Sufaid Dheri & 71.46 & 33.94 & 0.234 & 0.332 & 0.393 & 0.461 \\
\hline Suleman Khel & 71.50 & 33.90 & 0.233 & 0.333 & 0.396 & 0.467 \\
\hline Takhat Abad & 71.57 & 34.10 & 0.230 & 0.323 & 0.383 & 0.447 \\
\hline Urban & 71.50 & 34.04 & 0.232 & 0.325 & 0.385 & 0.449 \\
\hline Urban Area & 71.56 & 33.95 & 0.234 & 0.330 & 0.391 & 0.459 \\
\hline Urmur Bala & 71.73 & 33.86 & 0.238 & 0.340 & 0.401 & 0.473 \\
\hline Urmur Miana & 71.75 & 33.93 & 0.236 & 0.333 & 0.394 & 0.462 \\
\hline Urmur Payan & 71.75 & 33.96 & 0.234 & 0.329 & 0.390 & 0.456 \\
\hline Wad Pega & 71.65 & 34.00 & 0.234 & 0.326 & 0.386 & 0.450 \\
\hline
\end{tabular}



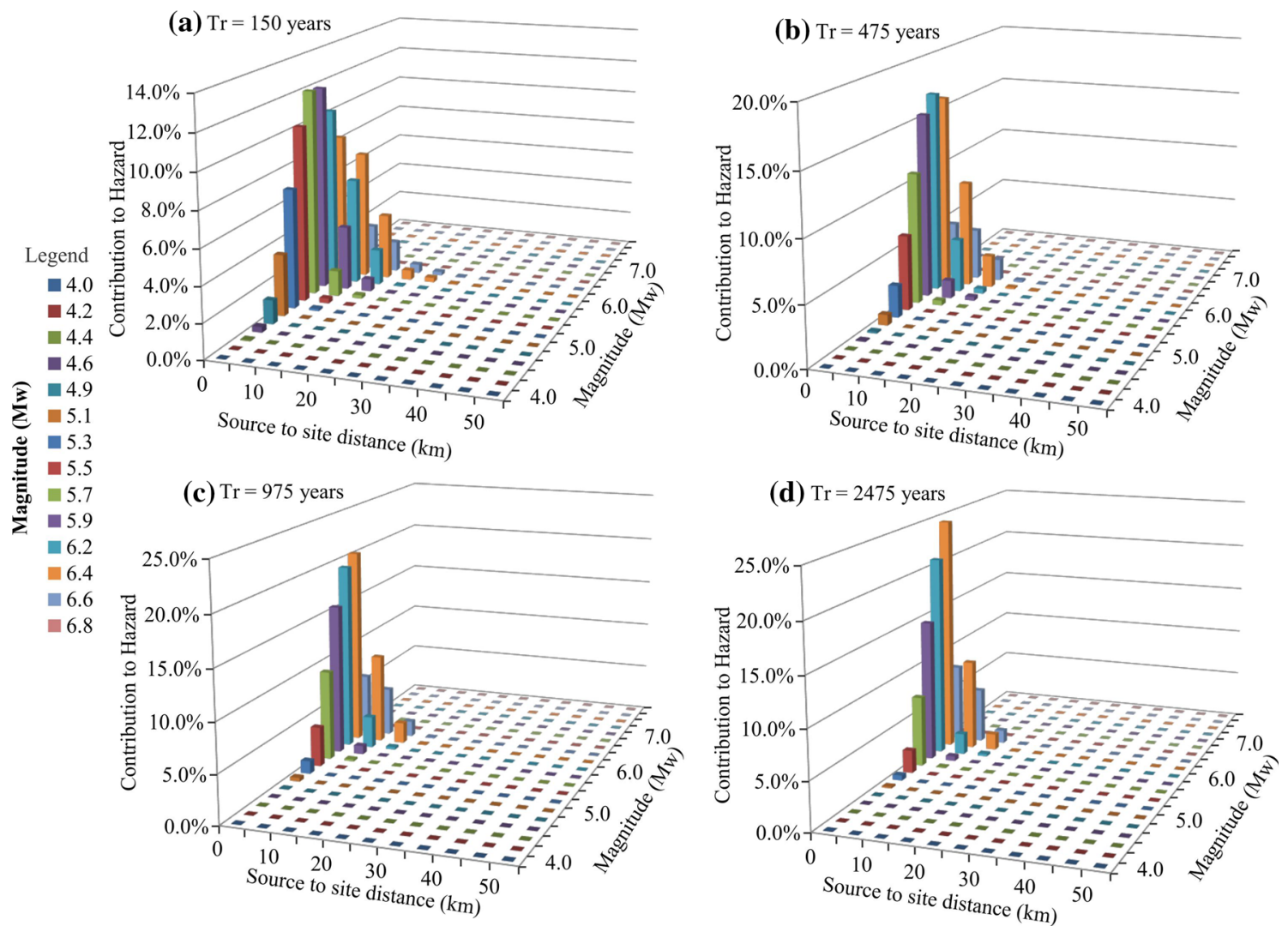

Figure 9. Disaggregation of probabilistic seismic hazard for the Peshawar District at return periods $\left(T_{\mathrm{r}}\right)$ of (a) 150 yr, (b) $475 \mathrm{yr}$, (c) $975 \mathrm{yr}$, and (d) $2475 \mathrm{yr}$.

Table 5. NEHRP site classification standards followed for different soil within the area.

\begin{tabular}{ll}
$\begin{array}{l}\text { Site } \\
\text { class }\end{array}$ & \multicolumn{1}{c}{ Definitions } \\
\hline A & Hard rock with shear wave velocity $>1500 \mathrm{~m} / \mathrm{s}$ \\
B & Rock with shear wave velocity to $(760-1500 \mathrm{~m} / \mathrm{s})$ \\
$\mathrm{C}$ & Very dense soil and soft rock with shear wave velocity \\
& $(360-760 \mathrm{~m} / \mathrm{s})$ \\
$\mathrm{D}$ & Stiff soil with shear wave velocity $(180-360 \mathrm{~m} / \mathrm{s})$ \\
$\mathrm{E}$ & Soil with shear wave velocity $<180 \mathrm{~m} / \mathrm{s}$ \\
$\mathrm{F}$ & Site-specific evaluations \\
\hline
\end{tabular}

map (velocity modelling) for the Peshawar District. Figure 10 shows the velocity modelling map of the studied area.

Other than the National Earthquake Hazard Reduction Program (NEHRP) code (1997) Borcherdt (1994) procedure for determining the amplification factor is also used (Khan and Khan 2016). The mathematical formulation of Borcherdt (1994) is given in equation (6).

Surface ground motion value maps have been developed in the following three ways: (i) by
NEHRP amplification factor, (ii) by Borcherdt (1994) amplification factor (equation 6) and (iii) by taking the geometric mean of the ground acceleration values obtained in (i) and (ii).

In order to get ground acceleration values, amplification factors given in NEHRP (1997) codes for spectral period of $0.2 \mathrm{~s}$ for soil site classes $\mathrm{C}$ and $\mathrm{D}$ were first interpolated between two defined values in table 7 and then multiplied with average PSHA hazard spectral acceleration values between 0.1 and $1.0 \mathrm{~s}$ period for the return periods of 150 , 475,975 and 2475 yr.

In the Borcherdt (1994) method, the calculated average PSHA hazard spectral acceleration values between 0.1 and $1 \mathrm{~s}$ period for the return periods of 150, 475, 975 and 2475 yr are multiplied with amplification factors through equation (6) to obtain surface acceleration values. The shear wave velocity for bedrock is taken as $V_{\mathrm{s} \text {, bedrock }}=$ $760 \mathrm{~m} / \mathrm{s}$. The exponential coefficient $\left(m_{a}\right)$ is unit less quantity and determined as $0.13,-0.04,0$ and 0 on the basis of average ground motion intensity level (PGA) of $0.28 g$ (150 yr), 0.42g (475 yr), 
Table 6. Acceleration (g) values for the return periods of 150, 475, 975 and 2475 yr at the ground surface.

\begin{tabular}{|c|c|c|c|c|c|c|c|c|}
\hline \multirow[b]{2}{*}{ Name } & \multirow[b]{2}{*}{ Long. } & \multirow[b]{2}{*}{ Lat. } & \multirow{2}{*}{$\begin{array}{c}V_{\mathrm{s} 30} \\
(\mathrm{~m} / \mathrm{s})\end{array}$} & \multirow[b]{2}{*}{$\mathrm{SC}$} & \multicolumn{4}{|c|}{$\begin{array}{l}\text { Acceleration values for different return } \\
\text { period at ground surface }\end{array}$} \\
\hline & & & & & $150 \mathrm{yr}$ & $475 \mathrm{yr}$ & $975 \mathrm{yr}$ & $2475 \mathrm{yr}$ \\
\hline Achini Bala & 71.46 & 33.90 & 344 & $\mathrm{D}$ & 0.47 & 0.60 & 0.72 & 0.85 \\
\hline Adezai & 71.56 & 33.77 & 323 & $\mathrm{D}$ & 0.48 & 0.63 & 0.74 & 0.89 \\
\hline Aza Khel & 71.65 & 33.80 & 488 & $\mathrm{C}$ & 0.44 & 0.60 & 0.73 & 0.88 \\
\hline Bada Ber Huri Zai & 71.58 & 33.87 & 274 & $\mathrm{D}$ & 0.47 & 0.61 & 0.73 & 0.86 \\
\hline Bada Ber Maryam Zai & 71.60 & 33.88 & 254 & $\mathrm{D}$ & 0.48 & 0.61 & 0.72 & 0.86 \\
\hline Bazid Khel & 71.56 & 33.93 & 287 & $\mathrm{D}$ & 0.47 & 0.60 & 0.71 & 0.84 \\
\hline Budhni & 71.66 & 34.04 & 224 & $\mathrm{D}$ & 0.47 & 0.57 & 0.68 & 0.81 \\
\hline Chaghar Matti & 71.49 & 34.11 & 222 & $\mathrm{D}$ & 0.46 & 0.56 & 0.67 & 0.80 \\
\hline Cham Kani & 71.64 & 33.97 & 254 & $\mathrm{D}$ & 0.47 & 0.58 & 0.69 & 0.82 \\
\hline Dag & 71.51 & 34.04 & 296 & $\mathrm{D}$ & 0.46 & 0.58 & 0.68 & 0.81 \\
\hline Garhi Sher Dad & 71.45 & 34.11 & 235 & $\mathrm{D}$ & 0.46 & 0.57 & 0.67 & 0.80 \\
\hline Gul Bela & 71.64 & 34.12 & 208 & $\mathrm{D}$ & 0.46 & 0.56 & 0.67 & 0.80 \\
\hline Haryana Payan & 71.56 & 34.05 & 228 & $\mathrm{D}$ & 0.47 & 0.57 & 0.68 & 0.81 \\
\hline Jogani & 71.47 & 34.16 & 247 & $\mathrm{D}$ & 0.47 & 0.57 & 0.67 & 0.80 \\
\hline Kafoor Dheri & 71.40 & 34.06 & 324 & $\mathrm{D}$ & 0.46 & 0.57 & 0.68 & 0.80 \\
\hline Kaniza & 71.52 & 34.07 & 231 & $\mathrm{D}$ & 0.47 & 0.57 & 0.68 & 0.80 \\
\hline Kankola & 71.63 & 34.05 & 222 & $\mathrm{D}$ & 0.47 & 0.57 & 0.68 & 0.80 \\
\hline Khatki & 71.56 & 34.15 & 214 & $\mathrm{D}$ & 0.46 & 0.56 & 0.67 & 0.80 \\
\hline Khazana & 71.60 & 34.05 & 216 & $\mathrm{D}$ & 0.47 & 0.57 & 0.68 & 0.81 \\
\hline Lala & 71.70 & 33.99 & 236 & $\mathrm{D}$ & 0.47 & 0.58 & 0.69 & 0.82 \\
\hline Laram & 71.57 & 34.01 & 288 & $\mathrm{D}$ & 0.46 & 0.58 & 0.68 & 0.81 \\
\hline Maryam Zai & 71.59 & 33.80 & 318 & $\mathrm{D}$ & 0.48 & 0.62 & 0.74 & 0.88 \\
\hline Mashu Gaggar & 71.54 & 33.85 & 295 & $\mathrm{D}$ & 0.48 & 0.61 & 0.73 & 0.87 \\
\hline Mattani & 71.47 & 34.06 & 380 & $\mathrm{C}$ & 0.46 & 0.57 & 0.68 & 0.80 \\
\hline Mira Kachori & 71.68 & 33.95 & 269 & $\mathrm{D}$ & 0.47 & 0.60 & 0.71 & 0.84 \\
\hline Mosa Zai & 71.61 & 33.95 & 279 & $\mathrm{D}$ & 0.47 & 0.59 & 0.70 & 0.83 \\
\hline Nahaqi & 71.65 & 34.08 & 212 & $\mathrm{D}$ & 0.46 & 0.57 & 0.67 & 0.80 \\
\hline Pajjagi & 71.55 & 34.04 & 227 & $\mathrm{D}$ & 0.47 & 0.57 & 0.68 & 0.81 \\
\hline Pakha Ghulam & 71.60 & 34.01 & 239 & $\mathrm{D}$ & 0.46 & 0.57 & 0.68 & 0.81 \\
\hline Palosi & 71.48 & 33.98 & 297 & $\mathrm{D}$ & 0.46 & 0.59 & 0.70 & 0.83 \\
\hline Panam Dheri & 71.41 & 34.10 & 366 & $\mathrm{C}$ & 0.46 & 0.57 & 0.67 & 0.80 \\
\hline Pashta Khara Payan & 71.52 & 33.93 & 320 & $\mathrm{D}$ & 0.46 & 0.60 & 0.71 & 0.84 \\
\hline Peshawar & 71.57 & 33.97 & 286 & $\mathrm{D}$ & 0.47 & 0.58 & 0.69 & 0.82 \\
\hline Regi & 71.44 & 33.99 & 316 & $\mathrm{D}$ & 0.46 & 0.58 & 0.69 & 0.82 \\
\hline Sarband & 71.50 & 33.92 & 300 & $\mathrm{D}$ & 0.47 & 0.60 & 0.71 & 0.85 \\
\hline Shahi Bala & 71.43 & 34.05 & 296 & $\mathrm{D}$ & 0.46 & 0.58 & 0.68 & 0.81 \\
\hline Sheikh Muhammad & 71.54 & 33.91 & 287 & $\mathrm{D}$ & 0.47 & 0.60 & 0.71 & 0.85 \\
\hline SheiKhan & 71.48 & 33.86 & 333 & $\mathrm{D}$ & 0.47 & 0.61 & 0.73 & 0.87 \\
\hline Sher Kera & 71.60 & 33.75 & 302 & $\mathrm{D}$ & 0.49 & 0.63 & 0.75 & 0.89 \\
\hline Soro Zai Bala & 71.64 & 33.86 & 309 & $\mathrm{D}$ & 0.47 & 0.61 & 0.73 & 0.87 \\
\hline Soro Zai Payan & 71.65 & 33.90 & 274 & $\mathrm{D}$ & 0.47 & 0.61 & 0.72 & 0.86 \\
\hline Sufaid Dheri & 71.46 & 33.94 & 301 & $\mathrm{D}$ & 0.47 & 0.59 & 0.71 & 0.84 \\
\hline Suleman Khel & 71.50 & 33.90 & 307 & $\mathrm{D}$ & 0.47 & 0.60 & 0.72 & 0.85 \\
\hline Takhat Abad & 71.57 & 34.10 & 216 & $\mathrm{D}$ & 0.47 & 0.57 & 0.68 & 0.80 \\
\hline Urban & 71.50 & 34.04 & 280 & $\mathrm{D}$ & 0.46 & 0.58 & 0.68 & 0.81 \\
\hline Urban Area & 71.56 & 33.95 & 276 & $\mathrm{D}$ & 0.47 & 0.59 & 0.70 & 0.83 \\
\hline Urmur Bala & 71.73 & 33.86 & 360 & $\mathrm{D}$ & 0.47 & 0.61 & 0.73 & 0.87 \\
\hline Urmur Miana & 71.75 & 33.93 & 324 & $\mathrm{D}$ & 0.47 & 0.60 & 0.71 & 0.84 \\
\hline Urmur Payan & 71.75 & 33.96 & 297 & $\mathrm{D}$ & 0.46 & 0.59 & 0.70 & 0.83 \\
\hline Wad Pega & 71.65 & 34.00 & 236 & $\mathrm{D}$ & 0.47 & 0.58 & 0.69 & 0.81 \\
\hline
\end{tabular}




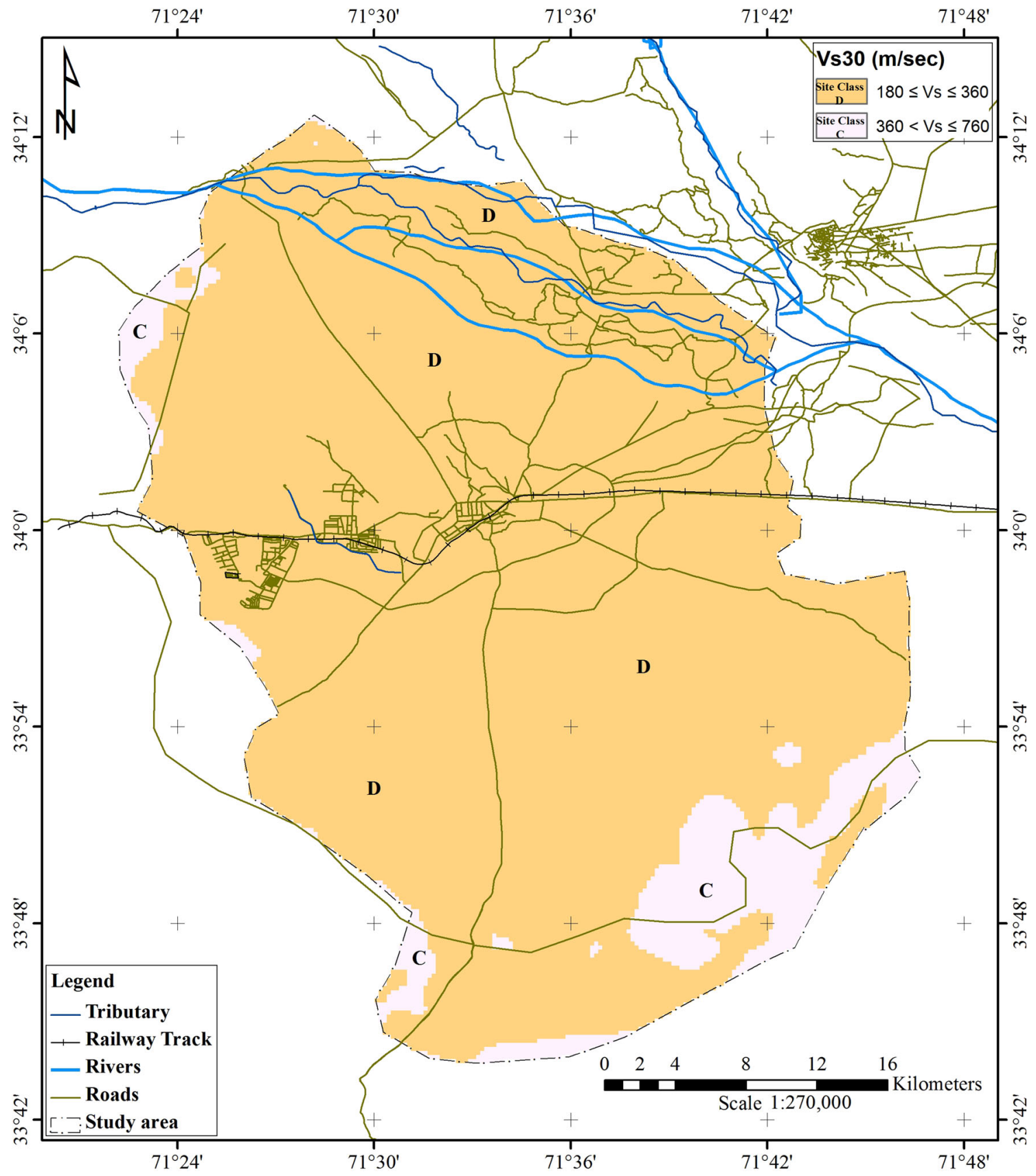

Figure 10. Shear wave velocity modelling map of the Peshawar District based on NEHRP classification.

$0.50 g$ (975 yr) and $0.57 g$ (2475 yr) at bedrock, respectively:

$$
F=\left(\frac{V_{\mathrm{s}, \text { bedrock }}}{V_{\mathrm{s} 30}}\right)^{m_{a}}
$$

where $F$ is the amplification factor and $V_{\mathrm{s} 30}$ the average shear-wave velocity (top $30 \mathrm{~m}$ depth). The amplification factors calculated from both the methods are listed in table 8 .
Surface ground motion maps are prepared for design spectra purpose for the return periods of 150, 475, 975 and 2475 yr using the NEHRP and Borcherdt (1994) method shown in figures 11 and 12, respectively. Surface ground motion values obtained by NEHRP and Borcherdt (1994) yielded different results; therefore, another map (figure 13) is generated by taking geometric mean of the acceleration values (Yagci and Ansal 2009) obtained from both the methods to get normalised final results of ground acceleration (table 6). 
Table 7. Amplification factor for soil site classes defined by NEHRP for spectral period of $0.2 \mathrm{~s}$.

\begin{tabular}{lccccc}
\hline $\begin{array}{l}\text { Site } \\
\text { class }\end{array}$ & $S_{\mathrm{S}} \leq 0.25$ & $S_{\mathrm{S}}=0.5$ & $S_{\mathrm{S}}=0.75$ & $S_{\mathrm{S}}=1.0$ & $S_{\mathrm{S}} \geq 1.25$ \\
\hline $\mathrm{A}$ & 0.8 & 0.8 & 0.8 & 0.8 & 0.8 \\
$\mathrm{~B}$ & 1 & 1 & 1 & 1 & 1 \\
$\mathrm{C}$ & 1.2 & 1.2 & 1.1 & 1 & 1 \\
$\mathrm{D}$ & 1.6 & 1.4 & 1.2 & 1.1 & 1 \\
$\mathrm{E}$ & 2.5 & 1.7 & 1.2 & 0.9 & 0.9 \\
\hline
\end{tabular}

Table 8. Amplification factor for soil site classes $C$ and $D$ calculated in this study from Borcherdt procedure and NEHRP codes for the return periods of 150, 475, 975 and $2475 \mathrm{yr}$.

\begin{tabular}{lllll}
\hline & \multicolumn{2}{c}{$\begin{array}{c}\text { Amplification factor using } \\
\text { NEHRP code }\end{array}$} & & \multicolumn{2}{c}{$\begin{array}{c}\text { Amplification factor using } \\
\text { Beturn } \\
\text { period }\end{array}$} & Site C & Site D & & Site C & Site D \\
\cline { 2 - 4 } & 1.140 & 1.280 & 1.071 & 1.073 \\
150 & 1.008 & 1.108 & 0.980 & 0.979 \\
975 & 1 & 1.028 & 1 & 1 \\
2475 & 1 & 1 & 1 & 1 \\
\hline
\end{tabular}

Based on the values in figure 13 the surface ground motion map of the studied area represents high and low acceleration values of $0.604 \mathrm{~g}$ to $0.632 g$ and $0.547 g$ to $0.575 g$, respectively, for a return period of $475 \mathrm{yr}$. The surface ground motion maps for the study area with return periods of $150,475,975$ and 2475 yr were developed at 1:270,000 scales through contouring software using the amplified average acceleration (figures 11-13).

\section{Results and discussion}

In the present study, design ground motion for the Peshawar District is computed using the PSHA consistent Cornell-McGuire (Cornell 1968; McGuire 1976) approach and using these results surface ground motion maps are proposed by including the local soil effects using the amplification factors suggested by NEHRP and Borcherdt (1994) procedures. The study area is divided by grid size of $0.1^{\circ} \times 0.1^{\circ}$, ground motion parameters are estimated at the site using hazard computing program Crisis 2015 Ver. 3.2 (Ordaz et al. 2015) using two GMPEs (Boore and Atkinson 2008; Akkar and Bommer 2010) at rock level. The hazard curves and UHS at rock level, PGA vs. return period and mean annual rate of exceedance vs. PGA are obtained. The hazard curve obtained from PSHA for the Peshawar District shows the annual frequency of exceedance (inverse of return period) for the PGA expected at the site. This curve defines seismic hazard for the Peshawar District as PGA $0.23,0.34,0.39$ and $0.45 g$ with return periods of $150,475,975$ and $2475 \mathrm{yr}$, respectively. The measured hazard contour maps of the Peshawar District in terms of the rock PGA values at $150,475,975$ and 2475 yr are shown in figure 8 .

The disaggregation for the PGA at return periods of $150,475,975$ and $2475 \mathrm{yr}$ at the Peshawar District reveals the earthquake-distance combinations that make the largest contribution to the total hazard. The disaggregation for the Peshawar District indicates that most of the hazard is contributed by an earthquake with a magnitude of $5.9-6.6$ at a distance of $5-11 \mathrm{~km}$ for the return period of $475 \mathrm{yr}$.

Local soil effects are included and integrated with ground motion values obtained for bedrock site conditions and using the amplification factors. Amplification factors for soil are obtained with NEHRP (1997) code and the Borcherdt (1994) method. The surface ground motion maps obtained from both the methods represent the different scenario of hazard. The difference is seen in the 

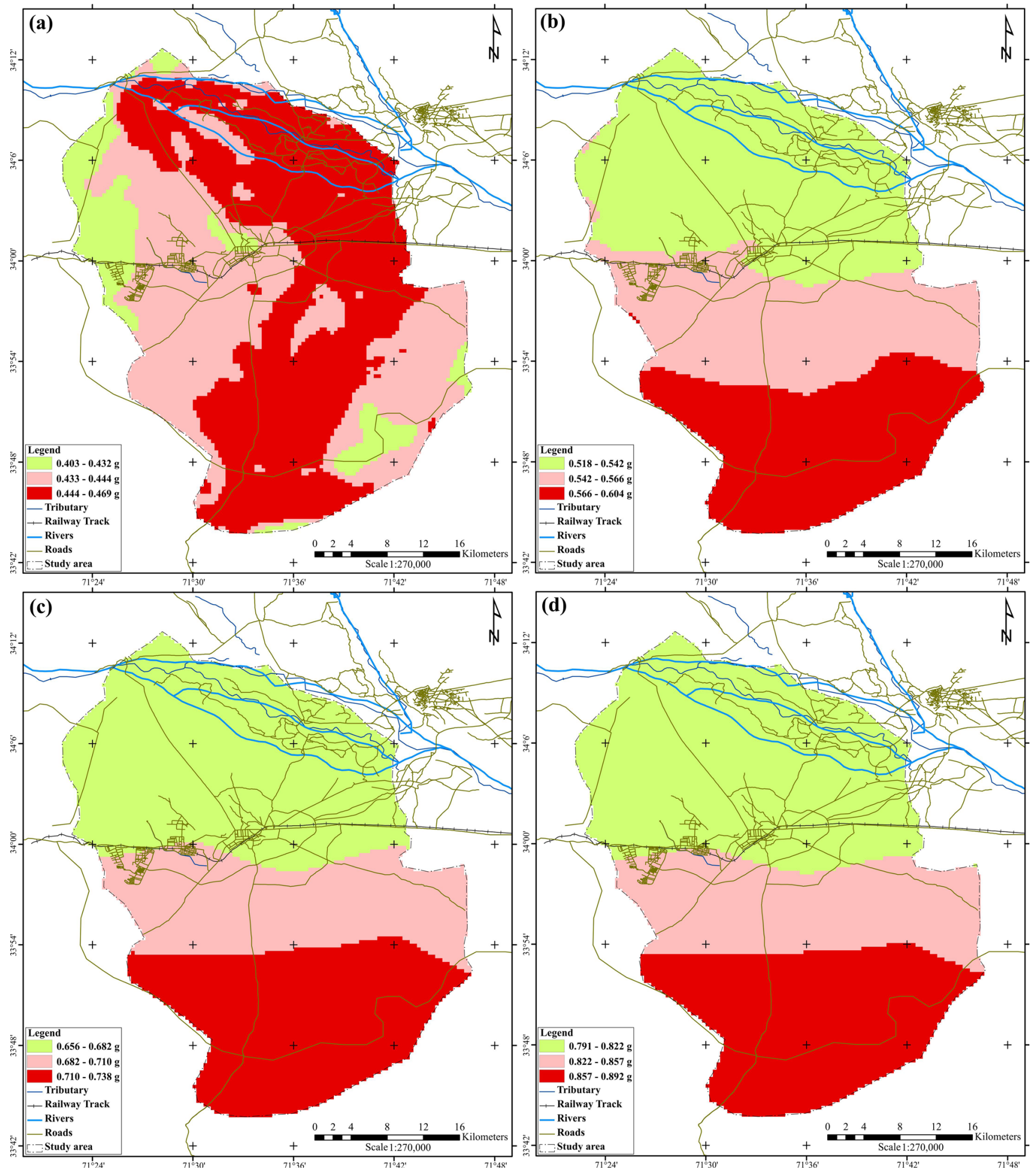

Figure 11. Amplified ground acceleration contour map of the Peshawar District using the Borcherdt (1994) method for return periods $\left(T_{\mathrm{r}}\right)$ of (a) $150 \mathrm{yr},(\mathbf{b}) 475 \mathrm{yr}$, (c) $975 \mathrm{yr}$, and (d) $2475 \mathrm{yr}$.

return period map of 150 yr. The Borcherdt method represents that the $40-50 \%$ of the area has high acceleration and NEHRP code method represents $\quad 60-70 \%$ area representing high acceleration values for the return period of $150 \mathrm{yr}$. For the return periods of 475, 975 and $2475 \mathrm{yr}$, 

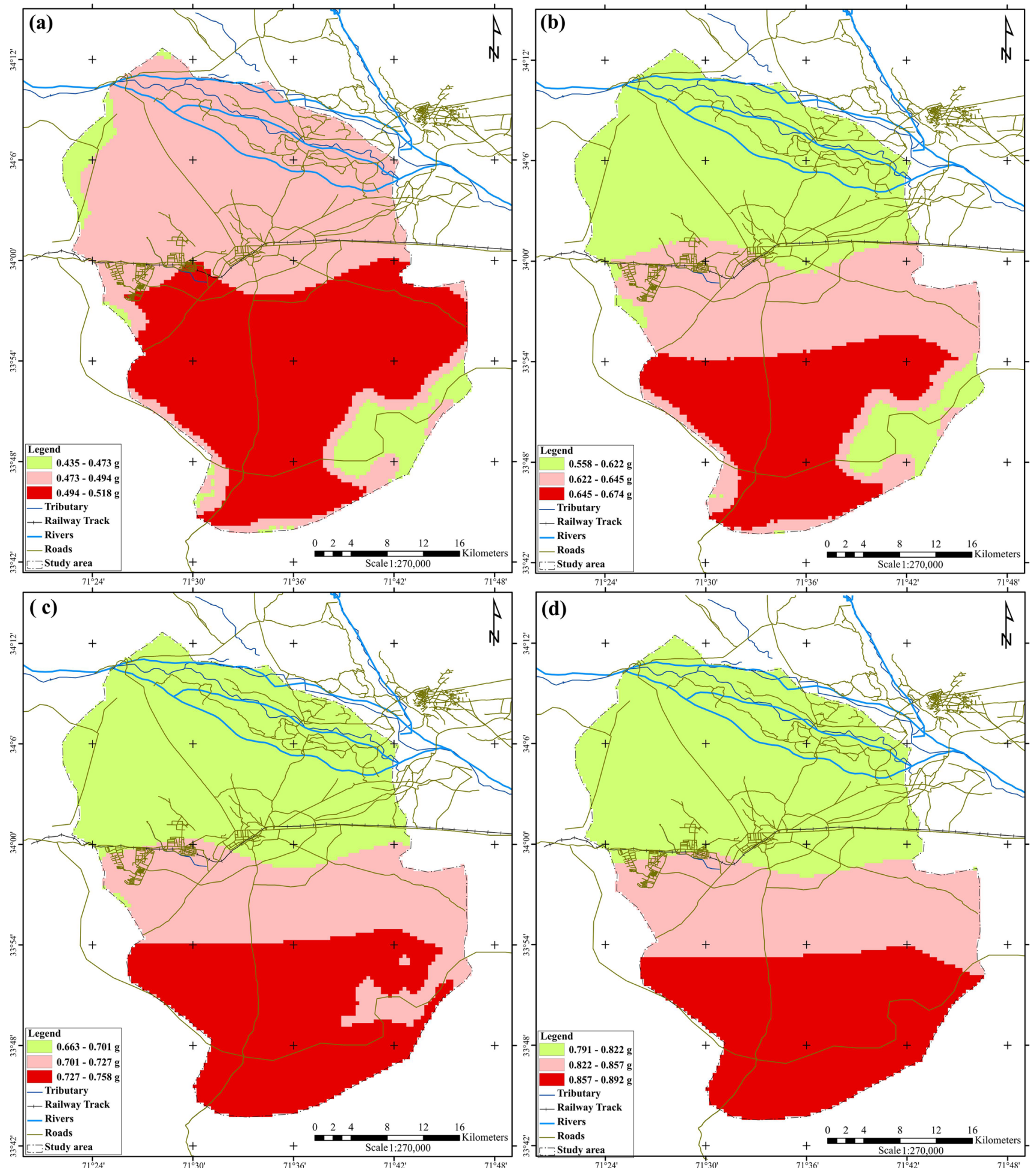

Figure 12. Amplified ground acceleration contour map of the Peshawar District using NEHRP (1997) code method for the return periods $\left(T_{\mathrm{r}}\right)$ of (a) $150 \mathrm{yr},(\mathbf{b}) 475 \mathrm{yr},(\mathbf{c}) 975 \mathrm{yr}$, and (d) $2475 \mathrm{yr}$.

the maps of accelerations from both the methods represent almost same percentage. Based on acceleration values (table 6) and figure 13, the central portion of study area involved the main city of the Peshawar District shows low-to-moderate amplification potential and seismic hazard than the surrounding area for the return periods of 150,475 , 975 and 2475 yr. 

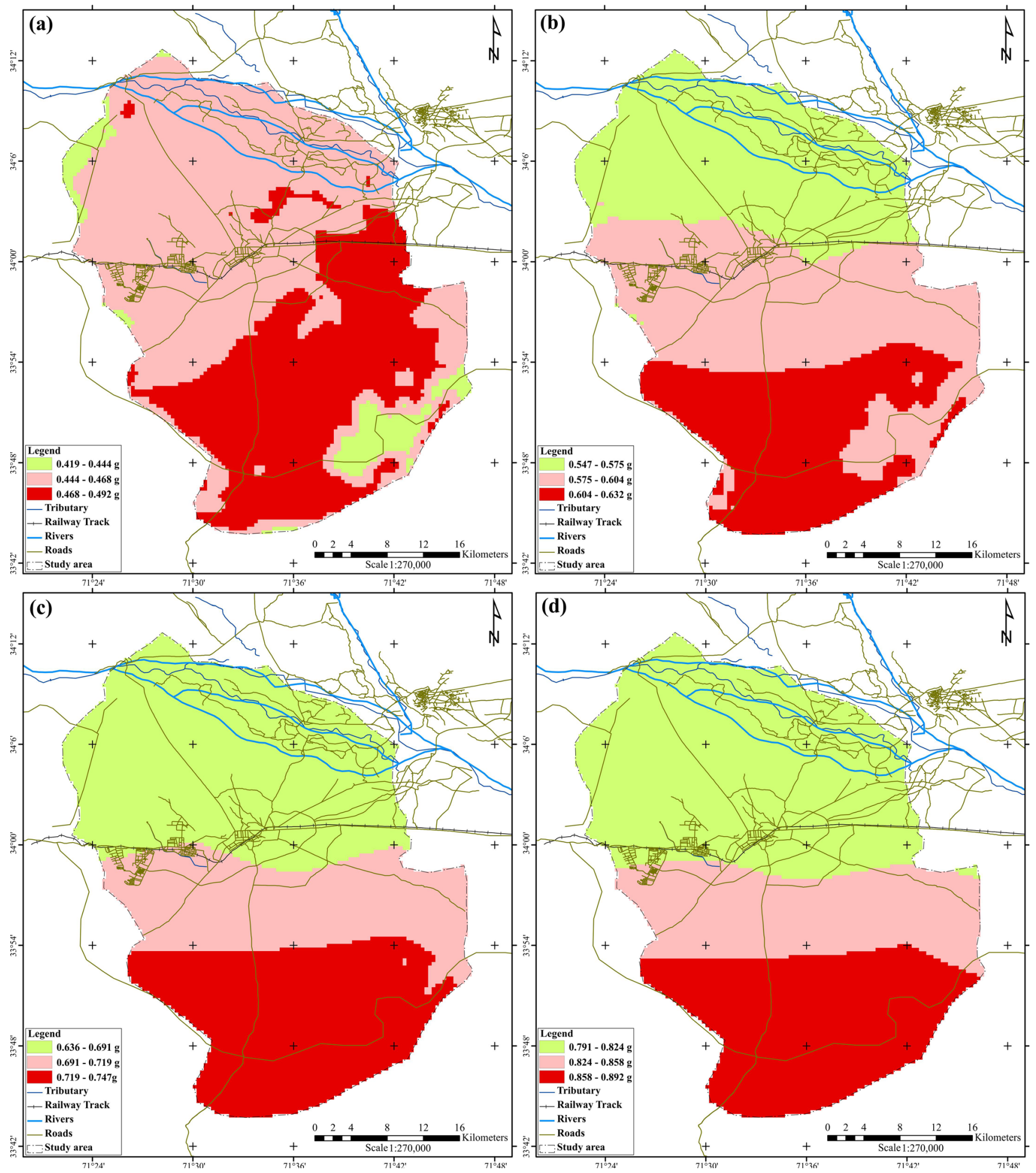

Figure 13. Amplified ground acceleration contour map of the Peshawar District, which results from superimposition (geometric mean) of map values in figures 11 and 12 for the return periods $\left(T_{\mathrm{r}}\right)$ of (a) $150 \mathrm{yr}$, (b) $475 \mathrm{yr}$, (c) $975 \mathrm{yr}$, and (d) $2475 \mathrm{yr}$.

\section{Conclusions}

Only a few studies have been carried out to estimate the distribution of seismic hazard in north Pakistan. A comparison of the previous studies of Bhatia et al. (1999), Pakistan Meteorological Department Map of 1999, Zhang et al. (1999), Geological Survey of Pakistan Seismic Zoning Map of 2006, BCP (2007), MonaLisa et al. (2007), Hashash et al. (2012), Rafi et al. (2012), Waseem 
et al. (2018), Saeed and Warnitchai (2012) and with the current study has been made (table 1). The comparison indicated that the results of these studies are different so independent PSHA study needs to be conducted for the study area. Therefore, an independent PSHA study based on the newly developed areal seismic zones and catalogue has been carried out. The ground motion values obtained for bedrock condition are higher than ground motion values proposed in BCP (2007). BCP (2007) proposed PGA value of $0.16 g$ to $0.24 g$ for the return period of $475 \mathrm{yr}$ while the PGA value of $0.34 \mathrm{~g}$ is obtained in this study. It is concluded that BCP (2007) is under-predicting the ground motion.

Soil characterisation carried out in this study indicates that the soil mostly falls in category D of soil classification according to NEHRP (1997) and most of the study area is occupied by this type of soil. As per the recommendation of $\mathrm{BCP}$ (2007), when the soil type is not known, then type $\mathrm{D}$ soil is a reasonable assumption and the velocity map obtained in the study fairly supports this assumption.

Based on the final amplified accelerations (geometric mean of acceleration values from NEHRP and Borcherdt methods) the surface hazard assessment maps refer to high and low acceleration values of $0.604-0.632 \mathrm{~g}$ and $0.547-0.575 \mathrm{~g}$, respectively, for the return period of $475 \mathrm{yr}$. The surface hazard assessment maps show that local soil effects are very important and prominent and they should be accounted in design ground motion values and the microzonation studies should be carried out for other important cities of Pakistan.

\section{Acknowledgements}

This study is part of MS thesis at the National Centre of Excellence in Geology (NCEG), University of Peshawar. The instrumentation used in this study and all logistic support for the fieldwork was provided by the NCEG, which is gratefully acknowledged.

\section{References}

Abrahamson N A and Silva W J 2008 Summary of the Abrahamson and Silva NGA ground motion relations; Earthq. Spectra 24 67-97.

Akkar S and Bommer J J 2007 Prediction of elastic displacement response spectra in Europe and the Middle East; Earthq. Eng. Struc. Dyn. 36 1275-1301.
Akkar S and Bommer J J 2010 Empirical equations for the prediction of $\mathrm{PGA}, \mathrm{PGV}$, and spectral accelerations in Europe, the Mediterranean region, and the Middle East; Seismol. Res. Lett. 81(2) 195-206.

Ambraseys N and Bilham R 2003 Earthquakes and associated deformation in northern Baluchistan 1892-2001; Bull. Seismol. Soc. Am. 93(4) 1573-1605.

Ambraseys N and Bilham R 2009 The tectonic setting of Bamiyan and seismicity in and near Afghanistan for the past twelve centuries; In: The destruction of the giant Buddha statues in Bamiyan, central Afghanistan, UNESCO's emergency activities for the recovering and rehabilitation of cliff and niches, UNESCO Special Publication (ed.) Margottini C 158 67-94, ISBN 978-448-0375-5.

Ambraseys N N and Bommer J 1990 Uniform magnitude revaluation for the strong-motion database of Europe and adjacent areas; Europ. Earthq. Eng. 4 3-16.

Anbazhagan P 2013 Method for seismic microzonation with geotechnical aspects; Disas. Adv. 6(4) 66-86.

Apel E, Burgmann R and Nagarajan B 2006 Geodetically constrained Indian plate motion and implications for plate boundary deformation; Eos, Trans. Am. Geophys. Union 85(52) T51B-1524, Fall meeting supplement.

BCP 2007 Building code of Pakistan seismic provision; In: Ministry of Housing and Works, Islamabad, Pakistan.

Bhatia S C, Kumar M R and Gupta H K 1999 A probabilistic seismic hazard map of India and adjoining regions; Ann. Geophys. 42 1153-1164.

Bilham R 1998 Slip parameters for the Rann of Kachchh, India, 16 June 1819, earthquake, quantified from contemporary accounts; In: Coastal tectonics (eds) Stewart I S and Vita-Finzi C, Geol. Soc. London 146 295-318.

Bilham R and Lodhi L 2010 Door Knockers of Mansurah: Strong shaking in a region of low perceived seismic risk, Sindh, Pakistan; Geol. Soc. Am. 471 29-37.

Bilham R, Lodhi S, Hough S, Bukhary S, Khan A M and Rafeeqi S F A 2007 Seismic Hazard in Karachi, Pakistan: Uncertain past, uncertain future; Seismol. Res. Lett. $78(6)$.

Boore D M and Atkinson G M 2008 Ground motion prediction equations for the average horizontal component of PGA, PGV, and 5\% damped PSA at spectral periods between $0.01 \mathrm{~s}$ and $10.0 \mathrm{~s}$; Earthq. Spectra. 24 99-138.

Boore D M, Joyner W B and Fumal T E 1997 Equations for estimating horizontal response spectra and peak acceleration from western north American earthquakes: A summary of recent work; Seismol. Res. Lett. 68 128-153.

Borcherdt R D 1994 Estimates of site-dependent response spectra for design (methodology and justification); Earthq. Spectra 10(4) 617-653.

Burbank D W and Raynolds R G H 1988 Stratigraphic keys to the timing of thrusting in terrestrial forland basins: Applications to the Northwestern Himalaya; In: News perspectives in basin analysis (eds) Kleinsphen J L and Paola C, Springer-Verlag, New York, pp. 331-351.

Burbank W D and Tahirkhali R A 1985 The magneto stratigraphy, fission track dating and stratific evolution of the Peshawar Intra mountain Basin, Northern Pakistan; Geol. Soc. Am. Bull. 96 539-552.

Burg J-P 2011 The Asia-Kohistan-India collision, review and discussion; In: Arc-continent collision: The making of an orogen, frontiers in earth sciences (eds) Brown 
D and Ryan P D, Springer-Verlag, Berlin Heidelberg, pp. 279-309.

Campbell K W and Bozorgnia Y 2008 NGA ground motion model for the geometric mean horizontal component of PGA, PGV, PGD and 5\% damped linear elastic response spectra for periods ranging from 0.01 to $10 \mathrm{~s}$; Earthq. Spectra 24 139-171.

Castellaro S and Mulargia F $2009 \mathrm{~V}_{\mathrm{S} 30}$ Estimates Using Constrained H/V Measurements; Bull. Seismol. Soc. Am. 99(2A) 761-773.

Chen Z, Burchfiel B C, Liu Y, King R W, Royden L H, Tang W, Wang E, Zhao J and Zhang W 2000 GPS measurement from eastern Tibet and their implications for India/Eurasia intercontinental deformation; J. Geophys. Res. 105 215-227.

Chiou B and Youngs R R 2008 An NGA model for the average horizontal component of peak ground motion and response spectra; Earthq. Spectra. 24 173-215.

Cornell C A 1968 Engineering seismic risk analysis; Bull. Seismol. Soc. Am. 58(5) 1583-1606.

Cornell C A and Vanmarcke E H 1969 The major influences on seismic risk; In: Proc. Fourth World Conferences on Earthquake Engineering, Santiago, Chile, A(1), pp. 6993.

DiPietro J A and Pogue K R 2004 Tectonostratigraphic subdivisions of the Himalaya: A view from the west; Tectonics 23.

Earle P S, Wald D J, Allen T I, Jaiswal K S, Porter K A and Hearne M G 2008 Rapid exposure and loss estimates for the May 12, $2008 \mathrm{mw} 7.9$ Wenchuan earthquake provided by the U.S. geological survey's PAGER system; In: The 14th World Conference on Earthquake Engineering Beijing, China.

Gansser A 1964 Geology of the Himalayas; Inter-Science Publication, London.

Gardner J K and Knopoff L 1974 Is the sequence of earthquakes in Southern California, with aftershocks removed, Poissonian?; Bull. Seismol. Soc. Am. 64(5) 13631367.

Gutenberg B and Richter C F 1944 Frequency of earthquakes in California; Bull. Seismol. Soc. Am. 4 185-188.

Hartzell S, Carver D and Williams R A 2001 Site response, shallow shear-wave velocity, and damage in Los Gatos, California, from the 1989 Loma Prieta Earthquake; Bull. Seismol. Soc. Am. 91(3) 468-478.

Hashash Y M, Kim B, Olson S M and Ahmad I 2012 Seismic hazard analysis using discrete faults in northwestern Pakistan. Part I: Methodology and evaluation; J. Earthq. Eng. 16(7) 963-994.

Heidarzadeh M, Pirooa M D, Zaker N H, Yalciner A C, Mokhtari M and Esmaeily A 2008 Historical tsunami in the Makran subduction zone off the southern coasts of Iran and Pakistan and results of numerical modeling; Ocean Eng. 35 774-786.

Idriss I M 2008 An NGA empirical model for estimating the horizontal spectral values generated by shallow crustal earthquakes; Earthq. Spectra 24(S1) 217-242.

Joyner W B and Boore D M 1993 Methods for regression analysis of strong-motion data; Bull. Seismol. Soc. Am. 83 469-487.

Kazmi A H and Jan M Q 1997 Geology and tectonics of Pakistan; Graphic Publishers, Karachi, Pakistan.
Khan S and Khan M A 2016 Mapping sediment thickness of the Islamabad city using empirical relationships: Implications for seismic hazards assessment; $J$. Earth Syst. Sci. 125(3) 623-644, https://doi.org/10. 1007/s12040-016-0675-0.

Khan M A, Aslam M, Hussain A, Ashraf M and Afridi A G K 2006 Geological map of North West Frontier Province, Pakistan (Colored, Scale 1:1,000,000); Geological Survey of Pakistan (Map Series).

Khan M A, Javed M W and Sayab M 2011 Fault map and associated database of fault parameters for Pakistan; WP-1 Interim Report, Earthquake Model of Middle East (EMME) International Project.

Kramer S L 1996 Geotechnical earthquake engineering, Prentice Hall, New Jersey, USA.

Martin S and Szeliga W 2010 A catalog of felt intensity data for 570 earthquakes in India from 1636-2009; Bull. Seismol. Soc. Am. 100(2) 562-569.

McGuire R K 1976 FORTRAN Computer program for seismic risk analysis, US Geological Survey, open file report, pp. 76-67.

MonaLisa, Khawaja A A and Jan M Q 2007 Seismic hazard assessment of NW Himalayan thrust belt using probabilistic approach; J. Earthq. Eng. 11 257-301.

Naseer A, Khan A N, Hussain Z and Ali Q 2010 Observed seismic behavior of buildings in Northern Pakistan during the 2005 Kashmir earthquake; Earthq. Spectra 26(2) 425449.

NEHRP 1997 National Earthquake Hazard Reduction Program (NEHRP) recommended provisions for seismic regulations for new building and other structures; Part-1: Provisions, building Seismic Safety Council, Washington, DC, USA.

NORSAR and PMD 2006 Seismic Hazard analysis for the cities of Islamabad and Rawalpindi; Pakistan Meteorological Department, 47p.

Oldham T 1883 A catalog of Indian earthquakes; Geol. Surv. India Memoir 19 163-215.

Ordaz M, Faccioli E, Martinelli F, Aguilar A, Arboleda J, Meletti C and D'Amico V 2015 CRISIS2015-Ver. 3.2: Program for computing seismic hazard; Instituto de Ingenieria, UNAM, Mexico.

PMD and NORSAR 2007 Seismic Hazard Analysis and Zonation for Pakistan, Azad Jammu and Kashmir, Pakistan Meteorological Department, 153p.

Quittmeyer R L, Farah A and Jacob K H 1979 The seismicity of Pakistan and its relation to surface faults; In: Geodynamics of Pakistan (eds) Farah A and DeJong K A, Geological Survey of Pakistan, Pakistan, pp. 271284.

Rafi Z, Lindholm C, Bungum H, Laghari H and Ahmed N 2012 Probabilistic seismic hazard analysis and zonation of Pakistan, Azad Jammu and Kashmir; Nat. Hazards 61 1317-1354.

Saeed Z and Warnitchai P 2012 Probabilistic Seismic Hazard Maps for Pakistan; In: 15th World Conference on Earthquake Engineering, Bangkok, Thailand.

Scordilis E M 2006 Empirical global relations converting $M_{\mathrm{s}}$ and $m_{\mathrm{b}}$ to moment magnitude; J. Seismol. 10(2) 225236.

Searle M P, Khan M A, Fraser J E, Gough S J and Jan M Q 1999 The tectonic evolution of Kohistan-Karakoram 
collision belt along the Kohistan Highway transect, North Pakistan; Tectonics 18(6) 929-949.

Shaltegger U, Zeilionger G, Frank M and Burg J-P 2002 Multiple Mantle sources during Island arc magnetism $\mathrm{U}-\mathrm{Pb}$ and $\mathrm{Hf}$ isotopic evidence from the Kohistan arc complex Pakistan; Terra Nova 44(6) 461-468.

Shen Z K, Zhao C, Yin A, Li Y, Jackson D, Fang P and Dong D 2000 Contemporary crustal deformation in East Asia constrained by Global Positioning System measurement; J. Geophy. Res. 105 572-573.

Tahirkheli R A 1982 Geology of the Himalaya, Karakorum, and Hindu Kush in Pakistan; Univ. Peshawar Geol. Bull. 1551.

Tahirkheli R A and Jan M Q 1979 A preliminary geological map of Kohistan and adjoining areas, N. Pakistan; Univ. Peshawar Geol. Bull. 11187.

Tinti S and Mulargia F 1985 Completeness analysis of a seismic catalog; Ann. Geophys. 3(3) 407-414.

Trifunac M D 1989 Threshold magnitudes which cause ground motion exceeding the values expected during next 50 yr in a metropolitan area; Geofizika 6 1-12.

Turnbull M L 2000 A discussion of the felt reports resulting from the Bundaberg earthquake, May 29 1997; In: Bundaberg: A regional perspective, Central Queensland University, Rockhampton, Qld, Centre for Social Science Research (eds) Neuenfeldt et al., pp. 63-78.

Wald D J and Allen T I 2007 Topographic slope as a proxy for seismic site conditions and amplification; Bull. Seismol. Soc. Am. 97(5) 1379-1395.

Corresponding editor: N V CHALAPATHI RAO
Waseem M, Spacone E and Lai C G 2018 Seismic hazard assessment of northern Pakistan; Nat. Hazards 90(2) $563-590$.

Weichert D H 1980 Estimation of the earthquake recurrence parameters for unequal observation periods for different magnitudes; Bull. Seismol. Soc. Am. 70 13371346.

Wills C J and Clahan K B 2006 Developing a map of geologically defined site-condition categories for California; Bull. Seismol. Soc. Am. 96(4A) 1483-1501.

Wills C J and Silva W 1998 Shear wave velocity characteristics of geologic units in California; Earthq. Spectra. 14(3) $533-566$.

Wills C J, Petersen M, Bryant W A, Reichle M, Saucedo G J, Tan S, Taylor G and Treiman J 2000 A siteconditions map for California based on geology and shear-wave velocity; Bull. Seismol. Soc. Am. 90(6B) 187208.

Yagci B and Ansal A 2009 Microzonation study in Balikesir; Teknik Dergi 20(1) 1313-1336.

Yong A, Hough S E, Abrams M J, Cox H M, Wills C J and Simila G W 2008 Site characterization using integrated imaging analysis methods on satellite data of the Islamabad, Pakistan, region; Bull. Seismol. Soc. Am. 98(6) 2679-2693.

Zhang P Z, Yang Z-X, Gupta H K, Bhatia S C and Shedlock K M 1999 Global seismic hazard assessment program (GSHAP) in continent Asia; Annali di Geofisica 42(6) $1167-1190$ 